\title{
Matematik Öğretiminde, Öğrenme Stilleri ve Önkoşul Öğrenmelere Dayalı Etkinliklerin Etkisi
}

\author{
Learning Styles in Teaching Mathematics and the Effect of these Activities \\ Based on Learning Preconditions
}

\section{Süleyman DOĞRU *}

Öz: Bu çalı̧̧mada, iki temel problem esas alınmıştır. Öncelikle; ilköğretim 5. sınıf matematik öğretiminde Kolb'un öğrenme stili ve ön koşul öğrenmelere dayalı hazırlanan etkinliklerin öğrencilerin matematik dersine yönelik tutumuna, öz yeterlik algısına, matematik kaygısına ve kalıcılığa etkisi araştııılmıştır. İkinci olarak; ilköğretim matematik öğretiminde, ön öğrenme eksikliklerinin giderilerek, Kolb öğrenme stillerine göre hazırlanan etkinliklerin uygulandığı sınıftaki öğrencilerin, etkinliklere ve sürece ilişkin görüssleri tespit edilmiştir. Bu kapsamda araştırmada, nitel ve deneysel yöntem birlikte kullanılmış̧ır. Araştırmanın çalışma grubunu, 2011-2012 eğitim öğretim yıll, Konya ili Selçuklu ilçesi Ahmet Acar İlköğretim Okulu’nda öğrenimlerine devam eden toplam 75 beşinci sınıf öğrencisinden oluşmaktadır. Araştırmanın veri toplama araçlarını; Öğrenme Alanı Başarı Testi, Matematik Tutum Ölçeği, Matematik Kaygısı Ölçeği, Matematiğe Karşı Öz Yeterlik Algısı Ölçeği, Kolb Öğrenme Stilleri Envanteri ve Öğrenci Görüşme Formu oluşturmuştur. Araştırmanın nicel boyutunu test etmek amaciyla veriler üzerinde, tek faktörlü ANCOVA ve tek faktör üzerinde tekrarlı ölçümler için tek faktörlü ANOVA (repeated measures) analizler yapılmıştır. Araştırmanın nitel boyutundan elde edilen veriler ise; betimsel istatistiklerle analiz edilmiştir. Araştırma bulgularından elde edilen sonuçlara göre; Öğrencilerin öğrenme stillerine göre; deney grubu öğrencilerinin kontrol grubuna göre tutum, öz yeterlik ve kalıcılık düzeylerinin artığı, kaygı düzeylerinin ise azaldığı, Ön öğrenme eksikliklerinin giderilmesi ve öğrenme stillerine dayalı hazırlanan etkinlik süreci ile ilgili deney grubu öğrencilerinin, "dersin işlenişsine yönelik", "sinıf ortamina yönelik" ve "matematik öğretimine yönelik" görüşlerinin genel olarak olumlu olduğu tespit edilmiştir.

\begin{abstract}
Anahtar sözcükler: İlköğretim Matematik Öğretimi, Kolb Öğrenme Stili Modeli, Öğrenci Davranışları
Abstract: This study is based on two fundamental problems. Firstly, the effect of activities prepared for elementary $5^{\text {th }}$ grades on the basis of Kolb's learning styles and the prerequisite learning skills upon students' attitude towards the mathematics class, self-efficacy perception, mathematics anxiety and retention was researched. Secondly, the opinions of the experimental group students about the learning process and activities, with whom the activities based upon Kolb's learning styles were practiced, as well as eliminating the prerequisite learning deficiencies, were determined. Within this framework, descriptive and experimental methods were used in this research. The participants in this study comprised 75 fifth graders who attended the Ahmet Acar Elementary School in Selçuklu, Konya, during the 2011-2012 academic year. The data collection tools for this research were the Learning Domain Success Test, the Mathematics Attitude Scale, the Mathematics Anxiety Scale, the Scale of Self-Efficacy in Mathematics, the Kolb Learning Style Inventory and the Student Interview Form. With the aim of testing the quantitative dimension of this research, single factoral ANCOVA was used on this data, and for repeated measures of a single factor, single factoral ANOVA was applied. The data acquired from the research's quantitative dimension were analyzed through descriptive statistics. From the results of this study: in view of the students' learning styles, it was found that when compared with the control group students', the experimental group students' attitude, self-efficacy and permanence levels all increased while their anxiety level decreased. It was determined that the opinions of the experimental group students about the activity process based upon learning styles and the elimination of the prerequisite deficiencies were in general positive towards "teaching the lesson", "classroom environment" and "teaching mathematics".
\end{abstract}

Keywords: Elementary Mathematics Teaching, Kolb Learning Styles Model, Student Attitudes

\footnotetext{
* Dr., Biruni Üniversitesi, Eğitim Fakültesi, Özel Eğitim Bölümü, İstanbul. dogruib@gmail.com
} 
Bilgi toplumunun temelini oluşturan eğitim, günümüzde yeni bir yer, güç ve değer kazanmıştır. İçinde bulunduğumuz bilgi ve yüksek teknoloji çağında, doğal olarak bir toplumun insanlarının sahip olduğu eğitimin niteliği, o ülkenin gelişmişlik düzeyini belirleyen ölçüsü olmuştur. Bunun için günümüzde bilgi ve eğitim; kalkınmanın, gelişmenin ve saygınlığın en etkili aracı olarak görülmektedir. Bir ülkenin kalkınmasında, bir bilgi toplumunun oluşturulmasında, ülkenin geleceği açısından matematik öğretimi de önemli bir yer tutmaktadır. Matematik eğitim ve öğretimi toplumda bireyin düşünce ve ufkunun gelişmesini sağlar. Bir bakış açısı, farklı bir açıdan yorum getirmeyi öğretir (Aydın 2003).

Matematik her ülkede olduğu gibi, ülkemizde de ilköğretimden yükseköğretime kadar en önemli dersler arasında yer almaktadır. Matematiğin önemi, yalnızca örgün eğitim programlarında ne kadar yer aldığı ile değil, asıl bilim ve teknolojinin damgasını vurduğu çağımızda, günlük yaşamımızı etkinlikle sürdürebilmemiz açısından onsuz olunamamasında yatmaktadır (Yenilmez 2010). Matematik bu kadar önemli bir işleve sahip olmasına rağmen öğrencilerin çoğu tarafından sevilmemekte, sıkıcı ve soyut bir ders olarak görülmektedir (Aksu 1985). Hatta matematik öğrencilerin çoğu için bir bulmaca işlemi olarak algılanmaktadır (Gray \& Tall 1992). Öğrencilerin çoğunun, matematiğe karşı bu şekilde olumsuz gözle bakmalarını etkileyen birçok faktör olabilir (Dursun \& Dede 2004). Bu faktörler matematik ile ilgili becerilerin kazanılmasında etkilidir. Bireyin eğitim hayatında ve meslek seçiminde etkili olabilecek bu faktörlerden birisi de matematik kaygısıdır (Bindak 2005). Matematik kaygısını etkileyen değişkenlerin başında, matematik yeteneği, algılanan matematik başarısı, matematik öz-yeterliği, aile çevresi, öğretmen tutumu ve öğretme metodunun olduğu belirtilmektedir (Haynes et al. 2004). Matematik kaygısının öz-yeterlilik ve akademik başarı kavramı ile ilişkili olduğu belirtilmektedir (Dursun \& Bindak 2011). Matematik öğretiminde konu anlamında matematik derslerinin içeriği ve derinliği her okul ve yaş grubuna değişmesine karşı, matematik eğitiminde erişilmesi gereken ana hedefler göz ardı edilmemesi gereken bazı nitelikler ve ölçütler vardır. Günümüzde özellikle ilköğretim de matematik öğretimine özel bir çaba sarf edilmelidir. Bu yaştaki öğrencilerin; matematiğin ne olduğunu, matematiğin değerini kavrayıcı, karşılaştıkları sorunları matematiksel problemlerle ifade edebilme ve çözme becerilerine yönelik, matematiksel işlem gücünü artırmayı amaçlayarak matematik öğretimi yapılmalıdır (Aydın 2003).

Öz yeterlilik algısı ilk kez, Bandura'nın Sosyal Öğrenme Kuramı'nda ortaya çıkan bir kavram olup, bireylerin olası durumlarla başa çıkabilmek için gerekli olan eylemleri ne kadar iyi yapabileceklerine ilişkin bireysel yargılarıyla ilgilidir (Bıkmaz 2006). Pajares'e (2003) göre yüksek düzeyde öz-yeterliliğe sahip bireyler, zorluk düzeyi yüksek olan çalışmalarla karş1 karşıya kaldıklarında daha rahat ve verimli olabilirler. Düşük öz-yeterlilik inancına sahip kimseler ise yapacakları çalışmaların gerçekte olduğundan daha da zor olduğuna inanırlar. Öğrencilerin öz-yeterlik algısını güçlendirmek için öğretmenlerin, öğrencilerin bireysel ihtiyaçlarına uygun öğretim yapmaları, her öğrencinin niteliklerine uygun çok çeşitli etkinliklere yer vermeleri, işbirliğine dayalı öğretim yaklaşımları kullanmaları, öğrencileri birbirleriyle karşılaştırmaya dayalı değerlendirme yaklaşımlarından kaçınmaları gerekir (Özgen \& Bindak 2008). Öğrencinin psikolojik durumlarının farkında olmak ve başarmaya yönelik algılarını güçlendirmeye çalışmak, onun herhangi bir duruma yönelik öz-yeterlik algısını olumlu etkileyecektir (Altun 2005). Davranışların dayandığ 1 psikolojik özellikler olarak tutumlar, yaşantılar yolu ile sonradan kazanılmakta, geçici olmayıp belli bir süre devamlılık göstermekte ve tepkide bulunmaya yönelik bir eğilim olma özelliği taşımaktadır. Tutumlar başarıyı, başarı da tutumları etkilemektedir (Saka \& Kıyıcı 2004). Bu nedenle matematikteki başarının yükselmesi için matematiğe yönelik olumsuz tutumun yıkılması gerekir (Aşkar \& Erdem 1986). 
Bilindiği gibi matematik biliminin diğer bilimlerden iki ana farkı vardır. Bunlardan birincisi müzik gibi, kendine has bir dilinin bulunması diğeri de basamaklı bir yapı özelliğini taşımasıdır. Basamaklı bir yapıya sahip olması, matematik yapanların matematiksel kavramlar arasındaki ilişkiyi çok iyi kurmasını zorunlu kılmaktadır. Bu her şeyden önce ön öğrenmelerin tam olmasını gerektirmektedir. Buna bağlı olarak da yeni kavramlar ile ön öğrenmelerin bir bütün olarak aynı bilgi yapısı kapsamında yerleştirilmesini zorunlu hale getirmektedir. Kavramların öğrenilmesi ve bilgi bütünlüğünün sağlanması için değişik etkinlikler ile öğrencinin kavram oluşturmasına katkı sağlamak büyük yarar sağlar. Eğer bu etkinliklerin hazırlanmasında öğrencilerin bireysel öğrenme stilleri de bilinir ise sorunun aşılması bir ölçüde kolaylaşmış olur (Elçi 2008). Öğrencilerin öğrenmeleri üzerinde etkili olduğu kabul edilen önemli özelliklerden biri de öğrenme stilleridir (Hein \& Budny 1999). Herkesin bir öğrenme stili vardır. Öğrenme stilleri bilgiyi nasıl öğrendiğimiz, nasıl problem çözdüğümüz, nasıl çalıştığımız, farklı aktivitelerde nasıl rol aldığımız, grup içinde nasıl tepki verdiğimiz, diğer bireylerle nasıl iletişim kurduğumuza etki eden bireysel tercihlerdir (Renzulli 1996). Öğrenme sürecini temel alarak deneyimsel öğrenme kuramını geliştiren Kolb (1984) öğrenme stilini, "bilgiyi alma ve işlemede kişisel olarak tercih edilen yöntem" olarak tanımlar. Kolb’un öğrenme stili etkinlik merkezli stillerden yaygın biçimde tercih edilenlerdendir (Biçer 2010).

Kolb (1984) dört öğrenme yaşantısı belirlemiştir. Bunlar; aktif yaşantı, somut yaşantı, soyut kavramlaştırma, yansıtıcı gözlemdir. Bu dört öğrenme yaşantısının birleştirerek öğrenme stillerini oluşturmuştur. Kolb’un kuramına göre bunlar: "ayrış̧ıran", "değiştiren", "özümseyen" ve "yerleştiren" öğrenme stilleridir. Ayrıştıran. Soyut Kavramsallaştırma ve Aktif Yaşantı öğrenme biçimlerini, Değiştiren Somut Yaşantı ile Yansıtıcı Gözlem öğrenme biçimlerini Özümseyen: Soyut Kavramsallaştırma ve Yansitıcı Gözlem öğrenme biçimlerini. Yerleştiren ise Somut Yaşantı ve Aktif Yaşantı öğrenme biçimlerini kapsamaktadır. (Arslan \& Babadoğan 2005).

Her bireyin baskın bir öğrenme stiline sahip olduğu düşünüldüğünde; farklı derslerde farklı deneyimler yaşamları sonucunda öğrenme tercihleri de derslere göre farklılaşma gösterebilecektir. Bu durumda öğrenme stillerinin sabitlenen bir özellik olmadığı, öğrenme ortamı düşünüldügünde dersten derse göre değişebileceği düşünülmektedir. Bu araştırmada da önkoşul öğrenmelere ve Kolb'un öğrenme stiline dayalı hazırlanan etkinliklerin ilköğretim 5. sınıf düzeyindeki öğrencilerin matematik dersine yönelik tutum, öz-yeterlik, kaygı ve başarı durumlarına etkisi ve öğrencilerin bu yöndeki etkinliklere ve sürece yönelik görüşlerinin alınmasının önemli olduğu düşünülmektedir.

$\mathrm{Bu}$ araştırmanın genel amacı; ilköğretim 5. sınıf matematik öğretiminde ön öğrenmelerdeki eksikliklerin giderilmesinde, Kolb'un öğrenme stili ve ön koşul öğrenmelere dayalı hazırlanan etkinliklerin öğrencilerin matematik dersine yönelik tutumuna, öz yeterlik algısına, matematik kaygısına ve akademik başarılarına etkisini sınamaktır. Bunun yanında, ilköğretim matematik öğretiminde öğrenci başarısının geliştirilmesi ve yoklanmasında, Kolb öğrenme stillerine göre hazırlanan etkinliklerin uygulandığı sınıftaki öğrencilerin etkinliklere ve sürece ilişkin görüşlerini belirlemektir.

$\mathrm{Bu}$ bağlamda araştırmada, aşağıda sıralanan alt problemler cevap aranmıştır:

1. Önkoşul öğrenmelere dayalı Kolb'un öğrenme stillerine göre hazırlanan ders etkinliklerinin kullanıldığı sınıfta öğrenciler ile bu tür yöntemlerin kullanılmadığı sınıftaki öğrencilerin

- Matematik başarıları,

- Matematiğe yönelik tutumları,

- Matematiğe yönelik öz-yeterlikleri 
- Matematik kaygıları arasında anlamlı bir fark var midır?

2. İlköğretim matematik öğretiminde öğrenci başarısının geliştirilmesi ve yoklanmasında, Kolb öğrenme stillerine göre hazırlanan etkinliklerin uygulandığı sınıftaki öğrencilerin etkinliklere ve sürece ilişkin görüşleri nedir?

\section{Yöntem}

\section{Araştırmanın Deseni}

Araştırma yöntemlerinin kullanımında geliştirilmiş etkili yöntemlerden biri karma desenli yöntemdir ve bu araştırmada da karma desenli yöntem kullanılmıştır. İlköğretim beşinci sınıf öğrencilerinin öğrenme stilleri, Matematik dersine yönelik tutumları, öz yeterlik algıları ve kaygıları ile Matematik dersi program kazanımlarının kalıcılık düzeylerinin belirlenmesi boyutu araştırmanın deneysel yönünü oluşturmaktadır. Araştırmanın bu yönü, öntest-sontest kontrol gruplu desen ile yürütülmüştür. Bu çalışmanın deseni, denek seçiminde yansız atamanın yap1lamamış olması nedeniyle de yarı-deneysel bir çalışma olarak nitelenebilir (Büyüköztürk 2012). Birbirine denk olan iki şubeden kura yoluyla biri deney, diğeri kontrol grubu olarak atanmış, her iki grupta da deney öncesi ve sonrası ölçümler yapılmış olup, araştırmanın deseni Tablo 1'de gösterilmiştir. Öğrencilerin Kolb’un öğrenme stillerine göre hazırlanan etkinliklere ve sürece ilişkin görüşlerini belirlenmesi boyutu ise araştırmanın nitel yönünü oluşturmaktadır.

Tablo 1. Araştırmanın Deneysel Deseni: Öntest-Sontest Kontrol Gruplu Desen

\begin{tabular}{|c|c|c|c|}
\hline Gruplar & Ön Ölçümler & İşlemler & Son Ölçümler \\
\hline Deney & $\begin{array}{l}\text { Matematik Öz yeterlik } \\
\text { Ölçeği, Matematik Kaygısı } \\
\text { Ölçeği, Tutum Ölçeği, } \\
\text { Akademik Başarı Testi }\end{array}$ & $\begin{array}{l}\text { Ön Öğrenme Eksikliklerinin } \\
\text { Giderilmesi ve Kolb’un } \\
\text { Öğrenme Stiline Göre } \\
\text { Hazırlanmış Etkinlikler }\end{array}$ & $\begin{array}{l}\text { Matematik Öz yeterlik } \\
\text { Ölçeği, Matematik Kaygısı } \\
\text { Ölçeği, Tutum Ölçeği, } \\
\text { Akademik Başarı Testi, } \\
\text { Öğrenci Görüşme Formu }\end{array}$ \\
\hline Kontrol & $\begin{array}{l}\text { Matematik Öz yeterlik } \\
\text { Ölçeği, Matematik Kaygısı } \\
\text { Ölçeği, Tutum Ölçeği, } \\
\text { Akademik Başarı Testi }\end{array}$ & $\begin{array}{l}\text { 2011-2012 Eğitim Öğretim } \\
\text { Y1lı İlköğretim 5. Sınıf } \\
\text { Matematik Öğretim Programı }\end{array}$ & $\begin{array}{l}\text { Matematik Öz yeterlik } \\
\text { Ölçeği, Matematik Kaygıs1 } \\
\text { Ölçeği, Tutum Ölçeği, } \\
\text { Akademik Başarı Testi }\end{array}$ \\
\hline
\end{tabular}

Çalışmadaki bağımlı değişkenler matematik tutumu, matematik öz-yeterlik algısı, matematik kaygısı ve kalıcılıktır. Araştırmanın bağımsız değişkeni, Kolb'un öğrenme stiline göre hazırlanan etkinliklere dayalı öğretim ve mevcut programa dayalı yapılan öğretimdir. Bu çalışmada, etkisi incelenen deneysel işlem Kolb öğrenme stillerine dayalı etkinliklerin etkisidir. Bu işlem deney grubunda Kolb'un öğrenme stillerine göre hazırlanan ders etkinliklerinin, kontrol grubunda ise matematik öğretim programına dayalı etkinliklerin uygulanmasına yönelik gerçekleştirilmiştir. Akademik başarı testi, araştırmanın bitiminden beş hafta sonra öğrencilerin kalıcılık düzeylerini belirlemek amacıyla tüm gruplara kalıcılık testi olarak tekrar uygulanmıştır.

\section{Çalışma Grubu}

$\mathrm{Bu}$ araştırmanın çalışma grubunu, Konya ili Selçuklu ilçesi Ahmet Acar İlköğretim Okulu 5/B ve 5/C sınıflarında öğrenimlerine devam eden toplam 75 öğrenciden oluşmaktadır. Bu iki şubeden biri deney $(n=37)$, diğeri kontrol $(n=38)$ grubu olarak seçkisiz yolla atanmıştır. Deney grubundaki öğrencilerin 17'si k1z, 20'si erkektir. Kontrol grubundaki öğrencilerin ise; 17'si k1z, 21'i erkektir. Araştırmanın uygulamasına başlamadan önce seçilen deney ve kontrol gruplarının akademik başarı yönünden denkliğini belirlemek için öncelikli olarak öğrencilerin Matematik dersine ait akademik başarı ortalamaları temin edilmiştir. Elde edilen puanların aritmetik ortalamaları bulunmuş ve aralarındaki fark ilişkisiz örneklemler için t-testi kullanılarak test edilmiştir. 
Tablo 2. Grupların 4.Sınıf Matematik Notlarının Denkliğine İlişkin t-testi Sonuçları

\begin{tabular}{|l|l|l|l|l|l|l|}
\hline Grup & N & X & S & sd & t & p \\
\hline Kontrol & 38 & 74.5180 & 12.8069 & 76 & .341 & .734 \\
\hline Deney & 37 & 75.5766 & 14.6213 & & & \\
\hline
\end{tabular}

Tablo 2'de görüleceği üzere deney grubundaki öğrenciler ile kontrol grubundaki öğrencilerin puan ortalaması arasında $\alpha=0,05$ düzeyinde manidar bir fark olmadığı gözlenmiştir $(p>0,05)$. Buna göre deneysel işlem sürecine başlamadan önce 4. sınıf matematik not ortalaması açısından deney ve kontrol grupları arasında başarı yönünden manidar bir fark olmadığı sonucuna varılabilir.

Uygunluk geçerliliği ve yordama geçerliği çalışmaları incelendiğinde, öğretmenlerin verdiği puanlar ile SBS ya da ÖSS gibi sınavlar arasında düşük bir ilişki elde edilmiştir (Güzeller 2005; Doğan ve Sevindik, 2011). Bu durumun bir kaynağının da öğretmenlerin vermiş olduğu notların sübjektifliğinden kaynaklandığı belirtilmektedir (Deniz \& Kelecioğlu 2005). Bu nedenle araştırmacı tarafından 4. sınıf birinci ve ikinci dönem ünite kazanımlarına yönelik çoktan seçmeli bir ölçme aracı hazırlanarak her iki gruba da uygulanmış ve karne notları ile elde edilen sonucun doğruluğu test edilmiştir. Grup Denkliği Başarı Testi, ilgili kazanımlara göre kaynaklardan yararlanılarak, eğitimde ölçme ve değerlendirme ve ilköğretim matematik eğitimi alanında çalışan uzmanların görüşleri çerçevesinde 30 soruluk bir ölçme aracı haline getirilmiştir. Gruplara göre alınan puanlar arasındaki fark ilişkisiz örneklemler için t-testi kullanılarak test edilmiştir. Grup denkliği başarı testi, deney grubunda bir ve kontrol grubunda iki öğrenci olmak üzere toplam üç öğrenciye devamsızlıkları nedeniyle uygulanamamıştır.

Tablo 3. Grup Denkliği Başarı Testine İlişkin t-testi Sonuçları

\begin{tabular}{|l|c|l|l|l|l|l|}
\hline Grup & N & X & S & sd & t & p \\
\hline Kontrol & 36 & 17.8611 & 4.7156 & 70 & .705 & .483 \\
\hline Deney & 36 & 17.0556 & 4.9739 & & & \\
\hline
\end{tabular}

Tablo 3 incelendiğinde, deney grubundaki öğrenciler ile kontrol grubundaki öğrencilerin puan ortalaması arasında $\alpha=0,05$ düzeyinde manidar bir fark olmadığ 1 gözlenmiştir $(\mathrm{p}>0,05)$. Buna göre deneysel işlem sürecine başlamadan önce akademik başarı açısından deney ve kontrol grupları arasında başarı yönünden manidar bir fark olmadığı sonucu tespit edilmiştir.

Deney grubu öğrencilerinin öğrenme stilleri bakımından nasıl bir dağılım gösterdiğini öğrenmek amacıyla “Kolb Öğrenme Stilleri Envanteri (KÖSE-III)” uygulanmıştır.

Tablo 4. Öğrencilerin Öğrenme Stillerinin Frekans ve Yüzde Dağılımları

\begin{tabular}{|l|c|c|}
\hline Öğrenme Stili & Frekans(f) & Yüzde(\%) \\
\hline Değiştiren & 13 & 35,14 \\
\hline Yerleştiren & 11 & 29,73 \\
\hline Ayrıștıran & 9 & 24,32 \\
\hline Özümseyen & 4 & 10,81 \\
\hline Toplam & 37 & 100,00 \\
\hline
\end{tabular}

Tablo 4 incelendiğinde, öğrencilerin \%35.14'ünün değiştiren, \%29,73'ünün yerleştiren, \%24,32'nin ayrıştıran, \%10,81'inin özümseyen öğrenme stiline sahip olduğu görülmektedir. Değiş̧iren stil, somut kavramsallaştırma ve yansıtıcı gözlem öğrenme yollarının bileşenidir. Algılayarak, hissederek ve gözlemleyerek öğrenmenin tercih edildiğini göstermektedir. Tablo 4'e göre, her bir stil grubundaki öğrenci sayısının azımsanamayacak düzeyde olduğu, diğer bir anlatımla öğ- 
rencilerin farkl1 öğrenme tercihlerinin var olduğu görülmektedir.

Deney grubunda yer alan öğrenciler sahip oldukları öğrenme stilleri açısından incelendiğinde, genel olarak tercih edilen öğrenme stilinin değiştiren olduğu; bunu yerleştiren, ayrıştıran ve özümseyen öğrenme stillerinin izlediği belirlenmiştir.

Öğrenme stillerinin belirlendiği birçok araştırma, öğrencilerin genellikle "değiştiren" öğrenme stiline sahip oldukları sonucunu destekler niteliktedir. (Coşkun 2011; Foney 1994; Koç 2009; Yurtseven 2010; Özer 2010).

\section{Veri Toplama Araçları}

Araştırmanın hipotezlerini test edebilmek amacıyla öğrencilerin belirlenecek içerik bağlamında matematiğe öz-yeterlik, matematik kaygısı, matematik tutum ölçeği ve matematik başarı puanlarına ihtiyaç duyulmaktadır. Bu verileri toplamak amacıyla kullanılan dört farklı ölçme aracına ilişskin bilgiler aşağıda verilmiştir.

\section{Başarı Testleri}

\section{Grup Denkliği Başarı Testi}

İlköğretim dördüncü sınıf Matematik dersi başarı testini geliştirmek amacıyla Matematik dersi dördüncü sınıf programı incelenmiş, program kazanımlarına göre sınıflandırılmıştır. Belirlenen kazanımların kazanılıp kazanılmadığını ortaya koymak amacıyla, her bir kazanım için en az bir adet soru olmak üzere toplam 30 sorudan oluşan çoktan seçmeli bir test hazırlanmıştır. Soruların hazırlanması sırasında matematik ders kitapları, yardımcı kitaplar çeşitli internet sitelerinden yararlanılmıştır. Ancak, sorular hiçbir kaynaktan aynen alınıp kullanılmamıştır. Hazırlanan soruların öğrenci seviyesine uygunluk ve bilimsel içerik açısından doğruluğunu belirlemek için matematik dersi öğretmenlerinin ve üç alan uzmanının görüşlerine başvurulmuştur. Öğretmenler ve uzmanlar tarafindan belirtilen görüşler doğrultusunda, başarı testine son şekli verilmiştir. Geliştirilen başarı testi, 120 kişilik bir öğrenci grubuna uygulanmış ve KR-20 katsayısı 0.86 bulunmuştur. Bu test, grup denkliğinin karşılaştırılmasında kullanılmıştır.

\section{Öğrenme Alanı Başarı Testi (ÖABT)}

Öğrencilerin başarı süreçlerini takip etmek amacıyla, İlköğretim beşinci sınıf matematik dersi 3. ve 4. ünitesine (Kesirler, oran ve orant1, çokgenler, simetri, ondalık kesirler, yüzdeler, uzunluk ölçme, çizgi grafiği, olasılık ve sıvı ölçme konuları) ait başarı testini geliştirmek amacıyla öncelikle Matematik dersi beşinci sınıf programı incelenmiş, programın kazanımları belirlenmiştir. Belirlenen kazanımlar doğrultusunda belirtke tablosu hazırlanmış ve her bir kazanım için en az 2 soru maddesi yazılmıştır. Soru maddeleri, ilköğretim 5. sınıf öğrencilerinin gelişim özellikleri göz önünde bulundurularak dörder seçenekli olarak oluşturulmuştur. Ölçme aracının kapsam geçerliğini sağlamak amacıyla maddenin ölçülmek istenen kazanımları ölçecek niteliğe sahip olup olmadığı, maddelerin yazım kurallarına uygunluğu, maddelerin anlam ve kapsam açısından uygunluğu, çeldiricilerin maddeye uygunluğu, doğru yanıtın maddeye uygunluğu ve bilimsel açıdan doğruluğu, testin ve maddelerin teknik özellikleri hakkında uzman görüşleri alınmıştır. Uzmanların görüşleri çerçevesinde maddelerde gerekli düzeltmeler yapılmıştır. Tüm kazanımları kavrayan çoktan seçmeli 70 soruluk ÖABT, daha önce bu üniteleri görmüş olan (İlköğretim 6. sınıf öğrencilerine) deney grubu dışındaki toplam 250 kişilik farklı bir gruba uygulanarak, test maddelerinin güçlük indeksleri ve ayırıcılık gücü indeksleri Microsoft Excel ve Statistica programı yardımıyla hesaplanmıştır. KR-20 güvenirlik katsayısı 0.96 çıkan ilk testte madde seçimi yapılırken orta güçlükteki maddelerin ve ayırt edicilik değeri 0,25 'ten yüksek olan 
maddelerin seçimine dikkat edilmiştir (Turgut 1984; Tekin 1993). Kazanımlar açısından ulaşılabilirlik incelenirken, sorulara verilen doğru cevap yüzdeleri ve frekans değerleri $\% 70$ kritik değeri ile karşılaştırılmıştır (Büyüköztürk, 2010). Davranışlar arasında ön ilişkinin olup olmadığını incelemek için tetrakorik korelasyon katsayıları kullanılmıştır. Bu ölçütlere göre aynı davranışı ölçen iki maddeden en iyisi seçilerek, 35 maddenin yer aldığ edilmiştir. Yapılan analizler sonucu testin ortalama madde güçlüğü 0.60 , KR- 20 güvenirlik katsayısı ise 0.94 olarak bulunmuştur. Son şekli verilen ve geçerlik güvenirlik çalışmaları yapılan 35 maddelik öğrenme alanı başarı testinin 3. ve 4. ünitesinde belirlenen kazanımları ölçtüğü ve güvenirliğinin yüksek olduğu sonucuna varılmıştır.

\section{Matematik Tutum Ölçeği (MTÖ)}

Öğrencilerin matematik dersine yönelik tutumlarını ölçmek amacıyla Baykul (1990) tarafından geliştirilen "Matematik Dersine Yönelik Tutum Ölçeği (MTÖ)" kullanılmıştır. Ölçek 30 maddeden oluşmaktadır. Araçta yanıtlayıcılar için beşli derecelendirme ölçeği kullanılmıştır. Ölçek 15 olumlu $(1,2,5,6,10,11,12,16,17,18,23,25,26,27)$ ve 15 olumsuz $(3,4,7,8,9$, $13,14,15,19,20,21,22,24,28,29,30)$ maddeden oluşmaktadır. Ölçek tek boyuttan (Öğrencilerin matematik dersine ilişkin tutumları) oluşmaktadır. Ölçeğin faktör yapısına ilişkin uygulanan faktör analizi, tek faktörle açıklanan varyansın \%56 olduğunu göstermiştir. Ölçekten elde edilen puanların alpha iç tutarlık katsayısı 0,96 bulunmuştur. Ölçekten alınabilecek en yüksek puan 150 iken en düşük puan 30 puandır. Ölçekten alınacak yüksek puan öğrencilerin matematik dersine ilişkin olarak olumlu bir tutum içinde olduğunu gösterir.

\section{Matematik Kaygısı Ölçeği (MKÖ)}

Matematik kaygısını ölçmek için, Bindak (2005) tarafından geçerlilik ve güvenirlik çalışmaları yapılarak ilköğretim öğrencileri için geliştirilen 10 maddelik matematik kayg1 ölçeği kullanılmıştır. Toplam varyansı \%51,7, Cronbach Alfa katsayıs1 0,84 ve test yarılama yöntemi ile hesaplanan güvenirlik katsayısı Sperman-Brown düzeltmesi ile 0,83 olarak bulunan olan tek faktörlü ölçekten elde edilen ölçümlerin geçerli ve güvenilir olduğu kanıtlanmıştır. Ölçeği cevaplayan her bir öğrenci her bir maddeye beş alt ölçek boyutunda tepkide bulunmaktadır. Bunlar; "her zaman, çoğu zaman, ara sıra, hemen hemen hiç ve hiçbir zaman" şeklindedir. Ankette bulunan kaygı için olumlu maddeler 5-4-3-2-1 şeklinde, kaygı için olumsuz maddeler ise 1-2-3-4-5 şeklinde puanlanmaktadır. Puanın yüksek olması matematik kaygısının yüksek olduğunu belirtmektedir. Ölçekten elde edilebilecek en yüksek kaygı puanı 50, en düşük kaygı puanı ise 10 olmaktadır. Ölçek, ilköğretim öğrencilerine uygulanarak, elde edilecek bulguların matematik kaygısı ile matematik becerisi arasındaki ilişkiyi ortaya çıkarmak, öğrencilerin matematik dersine karşı olan kaygılarının ne tür değişkenlere bağlı olduğunu belirlemek için kullanılmaktadır (Bindak 2005).

\section{Matematiğe Karşı Öz Yeterlik Algısı Ölçeği (MKÖA)}

Öğrencilerin öz yeterlik algılarını ölçmek amacıyla Umay’a (2002) ait “Matematiğe Karşı Öz Yeterlik Algısı (MKÖA)" öz yeterlik ölçeği kullanılmıştır. Ölçek 14 maddeden oluşmaktadır. Araçta yanıtlayıcılar için beşli derecelendirme ölçeği kullanılmıştır. Ölçek 8 adet olumlu (1, 2, $4,5,8,9,13,14)$ ve 6 olumsuz $(3,6,7,10,11,12)$ maddeden oluşmaktadır. Ölçek üç faktörden oluşmaktadır. Bunlar, 1) Matematik benlik algısı, 2) Matematik konularında davranışlarındaki farkındalık ve 3) Matematiği yaşam becerilerine dönüştürebilme olarak tanımlanmıştır. Birinci faktör 3., 10., 11., 12. ve 13. maddelerde; ikinci faktör 4., 5., 6., 7., 8. ve 9. maddelerde; üçüncü faktör 1., 2. ve 14. maddelerde yüklüdür. Ölçeğin alfa güvenirlik katsayısı toplam için 0,88 olarak hesaplanmıştır. Ölçekten alınabilecek en yüksek puan 90 en düşük ise 14 puandır. 
Ölçekten alınabilecek yüksek puan öğrencinin matematik dersine ilişkin olarak öz yeterlik algısının yüksek olduğunu dolayısıyla matematik dersi başarısı için kendisine olan güvenin yüksek olduğunu gösterir.

\section{Kolb’un Öğrenme Stilleri Envanteri-Versiyon III (KÖSE-III)}

$\mathrm{Bu}$ çalışmada öğrencilerin öğrenme stillerini belirlemek amacıyla Kolb tarafından geliştirilen ve Gencel (2006) tarafından Türkiye'de uygulanabilirliği üzerine çalışması yapılan "Kolb Öğrenme Stilleri Envanteri (KÖSE-III)" kullanılmıştır. Ölçeğin son şeklinde stil adları "Ayrlştırma", "Değiştirme", "Özümseme" ve "Yerleştirme” biçiminde değiştirilmiştir. Ölçek, "KÖSE-I (1971) ve KÖSE-II" (1981) versiyonlarında olduğu gibi 12 adet tamamlamalı maddeden oluşmaktadır (Gencel 2006).

Her bir maddede bulunan dört seçenek 1 ile 4 arasında şu şekilde puanlanmaktadır: " $1=H ı z l ı$ Davranirım, 2=Dikkatli olurum, 3=Mutlu olurum, 4=Kendi fikrimi oluştururum". Ölçekten alınan en düşük puan 12 , en yüksek puan 48 'dir. Bu puanlamadan sonra birleştirilmiş puanlar hesaplanmakta ve bu puanlar Soyut Kavramsallaştırma (S.K.) - Somut Deneyim (S.D.) ve Aktif Deneyim (A.D.) - Yansitıcı Gözlem (Y.G.) şeklinde elde edilmektedir. Bu işlem sonucunda elde edilen puanlar -36 ile +36 arasında değişmektedir. Soyut Kavramsallaştırma (S.K.) Somut Deneyim (S.D.) ile alınan pozitif puan öğrenmenin soyut, negatif puan ise soyut olduğunu; aynı şekilde, Aktif Deneyim (A.D.) - Yansıtıcı Gözlem (Y.G.) ile alınan puanlar, öğrenmenin aktif ya da yansıtıcı olduğunu ifade etmektedir. A.D. ve Y.G. işlemiyle elde edilen sayı koordinat sisteminde $\mathrm{x}$ eksenine, S.K.- S.D. işlemiyle elde edilen sayı ise y eksenine yerleştirilmektedir ve bu iki sayının kesiştiği alan öğrenme stilini göstermektedir (Gencel 2006).

\section{Öğrenci Görüş̧me Formu}

Bu çalışmada yarı yapılandırılmış görüşme tekniği kullanılmıştır. Performans görevleri süreci sonunda deney grubu öğrencilerinin Kolb'un öğrenme stillerine göre hazırlanan etkinliklere ve sürece ilişkin görüşlerini belirlemek için yedi soru sorulmuştur. Öğrenci Görüşme Formunun hazırlanmasında ön öğrenme eksikliklerinin giderilmesi ve Kolb'un öğrenme stillerine dayalı hazırlanan etkinlik süreçlerine yönelik uzman görüşlerinden elde edilen veriler esas alınmıştır. Hazırlanan görüşme formunda; "dersin işlenişine yönelik", "sinıf ortamına yönelik" ve “matematik öğretimine yönelik” öğrenci görüşleri tespit edilmeye çalış1lmıştır.

Görüşme soruları danışmanlarla birlikte hazırlanmış ve pilot çalışma ile test edilmiştir. Pilot çalışma sonucunda bazı sorular yeniden düzenlenerek görüşme formuna son hali verilmiştir. İçerik geçerliliğinin saptanması için görüşme formu, ilköğretim matematik eğitimi ve eğitim bilimleri alanlarında uzman üç ögretim üyesine verilmiş ve incelenmesi sağlanarak son biçimi verilmiştir. Bu çalışmaların sonunda, soru maddelerinin geçerliliği saptanmış ve sorular yeterli görülmüş̧ür.

\section{Verilerin Elde Edilmesi}

Araştırmaya iliş̧kin verileri elde etmek için gerçekleştirilen aşamalar aşağıda sunulmaktadır.

1. Araştırma, resmi izinlerin alınmasının ardından, Konya ili Selçuklu ilçesi Ahmet Acar İlköğretim Okulu 5/B ve 5/C sinıfları üzerinde yürütülmüştür. Yansız atama yolu ile 5/B sinıfi deney grubu, 5/C sinıfı kontrol grubu olarak belirlenmiştir.

2. Deneysel süreç öncesinde kura yöntemiyle seçilen deney grubunun öğrenme stilleri, "Kolb Öğrenme Stilleri Envanteri" ile belirlenmiştir. Ayrıca, deney ve kontrol grubunda Baykul (1990) tarafindan geliştirilen "Matematik Dersine Yönelik Tutum Ölçeği” matematik dersine karş1 tutumu belirlemede, Umay (2002) tarafindan geliştirilen "Matematik Öz yeterlik 
Ölçeği" matematik dersine ilişkin öz yeterlik algısını belirlemede ve Bindak (2005) tarafindan geliştirilen "Matematik Kaygı Ölçeği" matematik kaygısını belirlemede ve araştırmacı tarafından geliştirilen akademik başarı testi ölçüt olarak kabul edilerek ön test puanları elde edilmiştir.

3. Uygulama süreci 15 hafta sürmüştür. Her etkinlik öncesi deney grubu öğrencilerinin ön öğrenme eksiklikleri giderilmiştir. Bu işlem için, araştırmacı tarafından 5. sınıf 3. ve 4. ünite konuları için ön görülen ön öğrenme ilişkilendirilme tablosu hazırlanarak gerekli eğitim verilmiştir.

4. Süreç içerisinde her iki grupta da matematik dersine ilişkin performans uygulamalarının sadece okul içinde yapılmasına özen gösterilmiştir. Bunun için deney grubunun işlediği her matematik dersi, araştırmada uygulamaya konu olan okul içerisindeki matematik öğrenme merkezinde çalışmalarını sürdürmeleri sağlanmıştır. Süreç sonunda deney grubu ve kontrol grubuna, matematik tutum ölçeği, matematik kaygısı, matematik öz-yeterlik ölçeği ve başarı testi yeniden uygulanarak, tutum, kaygı, öz -yeterlik ve başarı testlerine ait son test puanları elde edilmiştir.

5. Deney ve kontrol gruplarında uygulanan 15 haftalık deneysel sürecin ardından MTÖ, MKÖ, MKÖA ve ÖABT son test olarak uygulanmıştır. ÖABT, araştırmanın bitiminden beş hafta sonra öğrencilerin ünite ile ilgili kavramları hatırda tutma düzeylerini belirlemek amacıyla tüm gruplara kalıcılık testi olarak tekrar uygulanmıştır. Görüşme Formu kullanılarak yapılan görüşmeler ise; öğretim yılının ikinci döneminde sadece deney grubundaki 24 öğrenciyle gerçekleştirilmiştir.

\section{Deney Süreci}

Deney ve kontrol grubu olarak belirlenen her iki sınıfta ders anlatımı düzenli olarak araştırmacı tarafından gerçekleştirilmiştir. Bu süreçlere ilişkin dersler, kontrol grubunda yapılandırmacı yaklaşımı temel alan mevcut Matematik öğretim programına göre işlenmiştir. Öğretim materyali çalışma öncesi araştırmacı tarafından hazırlanan ders etkinlikleri kullanılmıştır. Deney grubunda ise, 4E modeline dayalı olarak Kolb öğrenme stillerine göre hazırlanmış etkinlikler uygulanmiştır.

Deney grubunda, ilköğretim 5.sınıf Matematik dersinin "3. ve 4." Ünitesi (Kesirler, oran ve orantı, çokgenler, simetri, ondalık kesirler, yüzdeler, uzunluk ölçme, çizgi grafiği olasılık ve sıvı ölçme konuları) kazanımlarına yönelik 4E Modeline dayalı etkinlikler hazırlanmıştır. Her iki ünitede toplam 39 kazanım (3. Ünite 20, 4. Ünite 19 kazanım), deney sürecinde (15 hafta içerisinde) toplam 60 ders saati matematik dersi bulunmaktadır. Kazanımlar kendi içerisinde gruplanarak toplam on beş etkinlik haline getirilmiştir.

\section{Bulgular}

Araştırmanın birinci alt problemi "Kolb’un ögrenme stillerine göre hazırlanan ders etkinliklerinin kullanıldı̆̆g sinıfta ögrrenciler ile bu tür yöntemlerin kullanılmadiğl sinıftaki ögrencilerin matematiğe yönelik tutumları arasında manidar bir fark var mıdır?" şeklinde belirlenmiştir. Buna göre; öğrencilerin tutum ölçeğinden aldıkları ön ölçüm - son ölçüm puanlarının, gruplara göre önemli bir farklılık gösterip göstermediğini belirlemek amacı ile veriler, tek faktörlü kovaryans (ANCOVA) analizi ile incelenmiştir. Kovaryans analizine ilişkin sonuçlar Tablo 5 ve Tablo 6'da sunulmuştur. 
Tablo 5. Matematik Tutum Ölçeği Puanlarının Gruplara Göre Betimsel İstatistikleri

\begin{tabular}{|l|l|l|l|l|l|l|}
\hline Grup & \multicolumn{2}{l|}{ Ön Test } & \multicolumn{2}{l|}{ Son Test } & \multicolumn{2}{l|}{ Düzeltilmiş Ortalama } \\
\hline & N & \multicolumn{1}{l|}{$\overline{\boldsymbol{X}}$} & $\mathbf{N}$ & $\overline{\boldsymbol{x}}$ & \multicolumn{1}{l|}{ N } & $\overline{\boldsymbol{x}}$ \\
\hline Deney & 37 & 2.992 & 37 & 3.303 & 37 & 3.303 \\
\hline Kontrol & 38 & 2.912 & 38 & 3.013 & 38 & 3.012 \\
\hline
\end{tabular}

Tablo 5'te öğrencilerin Matematik Tutum Ölçeği ön ölçüm-son ölçüm sonuçlarına göre ortalama puanları incelendiğinde; deney grubu öğrencileri için 3.303, kontrol grubu öğrencileri için 3,013 olarak hesaplandığı görülmektedir. Ön ölçüm puanları kontrol edildiğinde, düzeltilmiş ortalama puanları deney grubu öğrencileri için 3.303, kontrol grubu öğrencileri için 3.013 olarak hesaplanmıştır. Grupların düzeltilmiş tutum ölçeği ortalama puanları arasında gözlenen farkın anlamlı olup olmadığına ilişkin ANCOVA sonuçları Tablo 6'da verilmiştir.

Tablo 6. Ön Ölçüm Sonuçlarına Göre Düzeltilmiş Matematik Dersine Yönelik Tutum Puanlarının Gruba Göre ANCOVA Analizi Sonuçları

\begin{tabular}{|l|c|c|c|l|l|}
\hline Varyansın Kaynağı & Kareler Toplamı & sd & Kareler Ortalaması & F & P \\
\hline Ön Ölçüm & .001 & 1 & .001 & .007 & .000 \\
\hline Grup & $\mathbf{1 . 5 6 9}$ & $\mathbf{1}$ & $\mathbf{1 . 5 6 9}$ & $\mathbf{9 . 1 9 0}$ & $\mathbf{. 0 0 3}$ \\
\hline Hata & 12.291 & 72 & .171 & & \\
\hline Toplam & 13.866 & 74 & & & \\
\hline
\end{tabular}

Tablo 6'da Matematik Dersine Yönelik Tutum Ölçeği ön ölçüm puanlarına göre düzeltilmiş son ölçüm puanlarının, gruplara göre anlamlı düzeyde farklılaştığı görülmektedir $[\mathrm{F}(1-72)=9.190$; $\mathrm{p}<0,005]$. Grupların düzeltilmiş son ölçüm puanları arasındaki farklılı̆̆ın nedenini saptamak amacıyla Bonferroni testi uygulanmıştır. Bonferroni testi sonuçlarına göre, deney grubu $(\bar{X}$ $=3,303)$ öğrencilerinin matematik dersine yönelik tutumlarının, kontrol grubu $(\bar{X}=3,012)$ öğrencilerinin matematik dersine yönelik tutumlarından daha yüksek olduğu görülmektedir.

Araştırmanın ikinci alt problemi "Kolb'un ögrenme stillerine göre hazırlanan ders etkinliklerinin kullanıldı̆̆g sinıfta öğrenciler ile bu tür yöntemlerin kullanılmadığ sinıftaki ögrencilerin matematiğe yönelik öz yeterlikleri arasında manidar bir fark var mıdır?" şeklinde belirlenmiştir. Buna göre; öğrencilerin Matematiğe Karşı Öz-Yeterlik Algısı ölçeğinden aldıkları ön ölçüm-son ölçüm puanlarının, gruplara göre önemli bir farklılık gösterip göstermediğini belirlemek amacı ile veriler, tek faktörlü kovaryans (ANCOVA) analizi ile incelenmiştir. ANCOVA analizine ilişkin sonuçlar Tablo 7 ve Tablo 8'de sunulmuştur.

Tablo 7. Matematiğe Karşı Öz Yeterlik Algısı Puanlarının Gruplara Göre Betimsel İstatistikleri

\begin{tabular}{|l|l|l|l|l|l|l|}
\hline Grup & \multicolumn{3}{|c|}{ Ön Test } & Son Test & \multicolumn{2}{l|}{ Düzeltilmiş Ortalama } \\
\hline & $\mathbf{N}$ & $\overline{\boldsymbol{X}}$ & $\mathbf{N}$ & $\overline{\boldsymbol{X}}$ & $\mathbf{N}$ & $\overline{\boldsymbol{X}}$ \\
\hline Deney & 37 & 3.077 & 37 & 3.524 & 37 & 3.521 \\
\hline Kontrol & 38 & 3.037 & 38 & 3.053 & 38 & 3.056 \\
\hline
\end{tabular}

Tablo 7'de öğrencilerin matematik öz yeterlik algıları ön ölçüm-son ölçüm sonuçlarına göre ortalama puanları incelendiğinde; deney grubu öğrencileri için 3.524, kontrol grubu öğrencileri için 3.053 olarak hesaplandığ 1 görülmektedir. Ön ölçüm puanları kontrol edildiğinde, düzeltilmiş ortalama puanları deney grubu öğrencileri için 3.521, kontrol grubu öğrencileri için 3.056 olarak hesaplanmıştır. Grupların düzeltilmiş öz yeterlik ölçeği ortalama puanları arasında gözlenen farkın anlamlı olup olmadığına ilişkin ANCOVA sonuçları Tablo 8'de verilmiştir. 
Tablo 8. Ön Ölçüm Sonuçlarına Göre Düzeltilmiş Matematiğe Karşı Öz Yeterlik Algı Puanlarının Gruba Göre ANCOVA Analizi Sonuçları

\begin{tabular}{|l|l|l|l|l|l|}
\hline $\begin{array}{l}\text { Varyansın } \\
\text { Kaynă̆ı }\end{array}$ & Kareler Toplamı & sd & Kareler Ortalaması & F & p \\
\hline Ön Ölçüm & .243 & 1 & .243 & 1.098 & .298 \\
\hline Grup & $\mathbf{4 . 0 6 2}$ & $\mathbf{1}$ & $\mathbf{4 . 0 6 2}$ & $\mathbf{1 8 . 3 4 6}$ & $\mathbf{. 0 0 0}$ \\
\hline Hata & 15.942 & 72 & .221 & & \\
\hline Toplam & 20.330 & 74 & & & \\
\hline
\end{tabular}

Tablo 8'de Matematiğe Karşı Öz-Yeterlik Alg1 Ölçeği ön ölçüm puanlarına göre düzeltilmiş son ölçüm puanlarının, gruplara göre anlamlı düzeyde farklılaştığı görülmektedir $[\mathrm{F}(1-72)=18.346$; $\mathrm{p}<0,005]$. Grupların düzeltilmiş son ölçüm puanları arasındaki farklılığın nedenini saptamak amacıyla Bonferroni testi uygulanmıştır. Bonferroni testi sonuçlarına göre, deney grubu $(\overline{\boldsymbol{X}}$ $=3.521)$ öğrencilerinin matematiğe karşı öz yeterlik algılarının, kontrol grubu $(\overline{\boldsymbol{X}}=3.056)$ öğrencilerinin matematiğe karşı öz yeterlik algılarından daha yüksek olduğu görülmektedir.

Araştırmanın üçüncü alt problemi “Kolb’un öğrenme stillerine göre hazırlanan ders etkinliklerinin kullanıldı̆̆ sinıfta ögrenciler ile bu tür yöntemlerin kullanılmadĭ̆ sinıftaki ögrencilerin "Matematik kaygıları arasında manidar bir fark var mıdır?" şeklinde belirlenmiş̧ir. Buna göre; öğrencilerin Matematik Kaygısı ölçeğinden aldıkları ön ölçüm-son ölçüm puanlarının, gruplara göre önemli bir farklılık gösterip göstermediğini belirlemek amacı ile veriler, tek faktörlü kovaryans (ANCOVA) analizi ile incelenmiştir (bk. Tablo 9 ve Tablo 10).

Tablo 9. Matematik Kaygısı Puanlarının Gruplara Göre Betimsel İstatistikleri

\begin{tabular}{|l|l|l|l|l|l|l|}
\hline Grup & Ön Test & Son Test & \multicolumn{2}{c|}{ Düzeltilmiş Ortalama } \\
\hline & N & $\overline{\boldsymbol{X}}$ & N & $\overline{\boldsymbol{X}}$ & $\mathbf{N}$ & $\overline{\boldsymbol{X}}$ \\
\hline Deney & 37 & 3.878 & 37 & 2.754 & 37 & 2.723 \\
\hline Kontrol & 38 & 3.757 & 38 & 3.762 & 38 & 3.792 \\
\hline
\end{tabular}

Tablo 9'da öğrencilerin matematik öz-yeterlik algıları ön ölçüm-son ölçüm sonuçlarına göre ortalama puanları incelendiğinde; deney grubu öğrencileri için 2.754 , kontrol grubu öğrencileri için 3.762 olarak hesaplandığı görülmektedir. Ön ölçüm puanları kontrol edildiğinde, düzeltilmiş ortalama puanları deney grubu öğrencileri için 2.723, kontrol grubu öğrencileri için 3.792 olarak hesaplanmıştır. Grupların düzeltilmiş matematik kaygısı ortalama puanları arasında gözlenen farkın anlamlı olup olmadığına ilişkin ANCOVA sonuçları Tablo 10'da verilmiştir.

Tablo 10. Ön Ölçüm Sonuçlarına Göre Düzeltilmiş Matematik Kaygısı Gruba Göre ANCOVA Analizi Sonuçları

\begin{tabular}{|l|l|l|l|l|l|}
\hline $\begin{array}{l}\text { Varyansın } \\
\text { Kaynă̆ı }\end{array}$ & Kareler Toplamı & sd & Kareler Ortalaması & F & $\mathbf{p}$ \\
\hline Ön Ölçüm & 11.484 & 1 & 11.484 & 41.739 & .000 \\
\hline Grup & $\mathbf{2 1 . 2 7 4}$ & $\mathbf{1}$ & $\mathbf{2 1 . 2 7 4}$ & $\mathbf{7 7 . 3 2 4}$ & $\mathbf{. 0 0 0}$ \\
\hline Hata & 19.809 & 72 & .275 & & \\
\hline Toplam & 50.327 & 74 & & & \\
\hline
\end{tabular}

Tablo 10'da Matematik Kaygısı Ölçeği ön ölçüm puanlarına göre düzeltilmiş son ölçüm puanlarının, gruplara göre anlamlı düzeyde farklılaştığ 1 görülmektedir $[\mathrm{F}(1-72)=77.324$; $\mathrm{p}<0,005]$. Grupların düzeltilmiş son ölçüm puanları arasındaki farklılığın nedenini saptamak amacıyla Bonferroni testi uygulanmıştır. Bonferroni testi sonuçlarına göre, deney grubu $(\overline{\boldsymbol{X}}$ $=2.723)$ öğrencilerinin matematik kaygılarının, kontrol grubu $(\overline{\boldsymbol{X}}=3.792)$ öğrencilerinin 
matematik kaygılarından daha düşük olduğu görülmektedir.

Araştırmanın dördüncü alt problemi “Kolb’un ögrenme stillerine göre hazırlanan ders etkinliklerinin kullanıldĭ̆g sinıfta öğrenciler ile bu tür yöntemlerin kullanılmadı̆̆ sinıftaki ögrencilerin kalıcılık düzeyleri arasında manidar bir fark var mıdır?" şeklinde belirlenmiştir. Buna göre; grupların Matematik dersi kalıc1lık düzeyleri öntest- sontest ve kalıc1lı testi ortalama puanları arasındaki farkı test etmek için tek faktör üzerinde tekrarlı ölçümler için tek faktörlü ANOVA (repeated measures) uygulanmıştır. Bunun için öncelikle aritmetik ortalama ( $\overline{\boldsymbol{X}}$ ) ve standart sapma (S) değerleri hesaplanmıştır. Deney ve kontrol gruplarının başarı testi öntest, sontest kalıcılık testi puanlarının, ortalama ve standart sapma değerlerine ilişkin bulgular Tablo 11'de verilmiştir.

Tablo 11. Deney ve Kontrol Gruplarının Başarı Testi (ÖABT) Öntest, Sontest ve Kalııılık Testi Puanlarının, Ortalama ve Standart Sapma Değerleri

\begin{tabular}{|l|l|l|l|l|l|l|l|l|l|}
\hline \multirow{2}{*}{ Gruplar } & \multicolumn{3}{|l|}{ Başarı Öntest } & \multicolumn{3}{l|}{ Başarı Sontest } & \multicolumn{2}{|c|}{ Kalıcık Testi } \\
\cline { 2 - 11 } & $\mathbf{N}$ & $\overline{\boldsymbol{X}}$ & $\mathbf{S}$ & $\mathbf{N}$ & $\overline{\boldsymbol{X}}$ & $\mathbf{S}$ & $\mathbf{N}$ & $\overline{\boldsymbol{X}}$ & $\mathbf{S}$ \\
\hline Deney & 37 & 19.162 & 6.02 & 37 & 26.919 & 6.32 & 37 & 26.108 & 4.88 \\
\hline Kontrol & 38 & 21.842 & 6.34 & 38 & 23.321 & 6.34 & 38 & 20.605 & 6.63 \\
\hline Toplam & 75 & 22.520 & 6.29 & 75 & 24.346 & 6.78 & 75 & 23.320 & 6.42 \\
\hline
\end{tabular}

Tablo 11 incelendiğinde, çalışma gruplarının ortalamaları arasında fark görülmektedir. Gözlenen bu farklılığın anlamlı olup olmadığını belirlemek için varyans çözümlemesi uygulanmıştır. Ayrıca, araştırmada uygulanan öğrenme stillerinin etkililiğini belirlemek üzere, eta-kare (effect size) korelasyon katsayısı da hesaplanmıştır. Elde edilen eta-kare değerleri ".01", ".06" ve ".14" düzeyinde olmak üzere sirasiyla "küçük", "orta" ve "geniş" etki büyüklüğü olarak yorumlanmıştır. Eta-kare değerleri 0.01-0.06 arasında ise küçük,0.06-0.14 arasında orta, 0.14 üzeri ise büyük etki büyüklüğünü göstermektedir (Büyüköztürk, 2009; Gren, Salkind ve Akey, 2000). Öğrencilerinin akademik başarı testi öntest-sontest ile kalıcılık puanlarının, kullanılan farklı değerlendirme yöntemlerine göre manidar bir fark gösterip göstermediğini test etmek için uygulanan ANOVA sonuçları Tablo 12'de verilmiştir.

Tablo 12. Deney ve Kontrol Grubundaki Öğrencilerin Kalıcılık Puanlarına Göre ANOVA Çözümlemesi Sonuçları

\begin{tabular}{|l|l|l|l|l|l|l|}
\hline Varyansın Kaynağı & K.T. & Sd & K.O. & $\mathbf{F}$ & $\mathbf{p}$ & $\boldsymbol{\eta}^{\mathbf{2}}$ \\
\hline Gruplar arası & 4001.795 & 74 & & & & \\
\hline Grup (Deney/Kontrol) & 389.965 & 1 & 389.965 & 7.882 & .006 & 0.097 \\
\hline Hata & 3611.830 & 73 & 49.477 & & & \\
\hline Gruplar içi & 5994.086 & 150 & & & & \\
\hline Ölçüm(Başarı) & 605.855 & 2 & 302.927 & 48.317 & .000 & 0.117 \\
\hline Grup Ölçüm & $\mathbf{7 9 5 . 5 2 6}$ & $\mathbf{2}$ & $\mathbf{3 9 7 . 7 6 3}$ & $\mathbf{1 2 . 6 4 5}$ & $\mathbf{. 0 0 0}$ & $\mathbf{0 . 1 4 8}$ \\
\hline Hata & 4592.705 & 146 & 31.457 & & & \\
\hline Toplam & 9995.881 & 224 & & & & \\
\hline
\end{tabular}

Tablo 12 incelendiğinde, ön test - son test ve kalıcılık testi ölçümlerini dikkate almadan deney ve kontrol gruplarının başarı testi ortalamalarını karşılaştırmada gruplar açısından anlamlı bir farklılaşma bulunmuştur $(\mathrm{F}=7.882, \mathrm{p}=.006<.05)$. Diğer taraftan grup değişkeninin etki büyüklüğüne bakıldığında $\left(\eta^{2}=0.097\right)$ öğrenme stillerine yönelik uygulamanın öğrencilerin kalıc1lık düzeyleri üzerinde orta etki büyüklüğüne sahip olduğu görülmektedir.

Grup değişkenini dikkate almadan sadece öntest- sontest ve kalıc1lık testi puanları arasında yapılan analizde, geniş etki $\left(\eta^{2}=0.117\right)$ düzeyinde anlamlı farklılık bulunmuştur $(\mathrm{F}=48.317$; $\mathrm{p}=.000<.05)$. Hem ön test - son test ve izleme testi sonuçlarını hem de deney ve kontrol grubu 
etkileşimini dikkate alarak yapılan analizde ise geniş etki büyüklügünde anlamlı farklılaşma bulunmuştur $\left(p=0,00\right.$ ve $\left.\eta^{2}=0,148\right)$. Grupların son test ortalama puanları ve kalıc1lı testi ortalama puanları ön test ortalama puanlarına göre daha yüksektir. Öte yandan son test ve kalıcılık testi puanları arasındaki fark anlamlı bulunmamıştır. Deney ve kontrol gruplarının zamana bağlı olarak ön test, son test ve kalıcılık testi başarı puanları arasında farkın, hangi ölçüm ya da ölçümlerden kaynaklandığını bulmak için yapılan zıtlık analizi sonuçları Tablo 13 'te sunulmuştur.

Tablo 13. Başarı-Grup Etkileşimine Göre Ön Test, Son Test, Kalıcılık Testi Karşıtlık Analizi Sonuçları

\begin{tabular}{|l|l|l|c|l|l|l|l|}
\hline Varyansın Kaynağı & Ölçümler & K.T. & sd & K.O. & $\mathbf{F}$ & $\mathbf{p}$ & $\eta^{2}$ \\
\hline Başarı*Grup & Sontest-Öntest & 129.988 & 1 & 129.988 & 7.882 & .006 & .097 \\
\hline Hata & Sontest-Öntest & 1203.943 & 73 & 16,492 & & & \\
\hline
\end{tabular}

Tablo 13'te görüldüğü gibi, deney ve kontrol gruplarının başarı testi puanları, son test ile ön test arasında $(\mathrm{p}=0,06)$ anlamlı düzeyde farklı bulunmuştur. Farkın etki büyüklüğü son test ile ön test arasında $\eta^{2=} 0,17$ düzeydedir. Bu sonuçlara göre deney grubunda uygulanan öğrenme stillerinin kontrol grubuna göre, öğrencilerin başarılarını daha çok artırdığı görülmüştür. $\mathrm{Bu}$ bulgu, Kolb'un öğrenme stillerine göre düzenlenen matematik dersini alan öğrencilerin kalıcılık düzeylerinin uygulama sonrasında ve daha sonra yapılan ölçümlerde anlamlı ölçüde artığını, uygulama sonrasındaki kalıcılık düzeylerinin ise daha sonra yapılan izleme çalışmalarındaki ölçüm sonuçlarından farklılaşmadığını, yani uygulamanın etkisinin devam ettiğini göstermektedir.

Araştırmanın beşinci alt problemi “ilköğretim matematik ögretiminde ögrenci başarısının gelişstirilmesi ve yoklanmasında, Kolb ögrenme stillerine göre hazırlanan etkinliklerin uygulandığ sinıftaki öğrencilerin, etkinliklere ve sürece ilişkin görüşleri nelerdir?" şeklinde belirlenmiştir. Buna göre; öğrencilere açık uçlu sorular sorulmuş, ön öğrenme eksikliklerinin giderilmesi ve öğrenme stillerine dayalı hazırlanan etkinlik süreci ile ilgili görüşleri alınmıştır. Öğrencilerin cevapları; "dersin işlenişine yönelik", "sınıf ortamına yönelik" ve "matematik öğretimine yönelik" olmak üzere üç tema altında toplanmıştır. Aşağıda bu temalara ilişkin olarak öncelikle, deney grubundaki öğrencilerin genel görüşleri tablolarda özetlenmiş, daha sonra direk alıntılarla bazı öğrencilerin görüşlerine yer verilmiştir.

\section{Dersin İşlenişine Yönelik Öğrenci Görüşleri}

Öğrencilere "dersin işlenişine yönelik" ana temasına ait iki adet açık uçlu soru sorulmuştur. Öğrencilerin, "Etkinlikler matematik dersini eğlenceli hale getirdi mi?" ve "Etkinlikler matematik dersinde aktif olmanı sağladı mı?" sorularına verdikleri yanıtlar Tablo 14'te gösterilmiştir.

Tablo 14. Dersin İşlenişine Yönelik Öğrenci Görüşlerine Ait Bulgular

\begin{tabular}{|l|l|l|l|}
\hline Dersin işlenişine yönelik; & Evet & Hayır & Bazen \\
\hline Etkinlikler matematik dersini eğlenceli hale getirdi mi? & 23 & - & 1 \\
\hline Etkinlikler matematik dersinde aktif olmanı sağladı mı? & 23 & - & 1 \\
\hline
\end{tabular}

Tablo 14 incelendiğinde, "Etkinlikler matematik dersini eğlenceli hale getirdi mi?", "Etkinlikler matematik dersinde aktif olmanı sağladı mı?" sorularına sadece bir öğrencinin bazen yanıtını verdiği görülmektedir.

Diğer yandan dersin eğlenceli hale gelmesi ve derse aktif katılımın sağlanması ile ilgili olumsuz görüş bildiren hiç öğrenci olmadığ tespit edilmiştir. Öğrencilerin hemen hemen hepsi, dersin etkinliklerle oldukça eğlenceli ve etkinliklerin derse aktif katılımın sağladığını ifade 
etmişlerdir. Aşağıda bu bulguyu destekleyen bazı öğrencilerin ifadelerine yer verilmiştir:

"Etkinliklerin çoğu günlük karşılaştığımız olaylardan olduğu için eğlenceli geldi...".

“...Etkinliklerden büyük zevk aldım. Çünkü oyun oynayarak, boyayarak ögrendim. Arkadaşlarımla tartışmam, düşüncemi söylemem güzeldi”.

"Etkinlikler matematik dersini ĕglenceli hale getirdi. Derse gelirken daha rahattim...".

“...Özellikle resimli etkinlikler ve benim görüşümü alan etkinliklerden zevk aldım".

"Etkinlikler matematik dersinde aktif olmanı sağladı mı? sorusuna ilişkin öğrenci görüşleri ise;

"Özellikle geometride yaptı̆̆ım etkinlikler çok güzeldi. Sanki matematik değil de görsel sanatlar, beden eğitimi gibiydi. Derse katıldım".

"Matematik dersinde önceleri bazı arkadaşlarımız sürekli konuşuyordu. Sizinle işlediğim derste ben de ve önceden konuşmayan arkadaşlarım da derse katıldı".

"Sadece benim değil, bütün sinıfin aktif olmasını sağladı ...".

"Yapabildiklerimden hoşlanmak derse katılmamı sağladı ...".

\section{Matematik Öğretimine Yönelik Öğrenci Görüşleri}

Öğrencilere "sınıf ortamına yönelik" ana temasına ait dört adet açık uçlu soru sorulmuştur. Öğrencilerin, "Etkinlikler akademik başarını artırdı mı?”, "Etkinlikler öğrenme üzerinde etkili miydi?", "Etkinlikler matematiğe yönelik kaygı/korkunu azalttı mı?" ve "Etkinlikler sonucunda kendine güvenin arttı mı?" sorularına verdikleri yanıtlar Tablo 15'de gösterilmiştir.

Tablo 15. Matematik Öğretimine Yönelik Öğrenci Görüşlerine Ait Bulgular

\begin{tabular}{|l|c|c|c|}
\hline Matematik öğretimine yönelik; & Evet & Hayır & Bazen \\
\hline Ön öğrenme etkinlikleri akademik başarını artırdı mı? & 24 & - & - \\
\hline Ön öğrenme etkinlikleri öğrenme üzerinde etkili miydi? & 24 & - & - \\
\hline Etkinlikler matematiğe yönelik kaygı/korkunu azalttı mı? & 24 & - & - \\
\hline Etkinlikler sonucunda kendine güvenin arttı mı? & 24 & - & - \\
\hline
\end{tabular}

Tablo 15 incelendiğinde öğrencilerin, matematik öğretimine yönelik tüm sorulara olumlu cevap verdikleri görülmektedir. Öğrencilerin tamam1, ön öğrenme eksikliklerinin giderilmesi ve Kolb'un öğrenme stillerine dayalı etkinliklerle yapılan matematik öğretiminin, başarılarını artırdığı, öğrenmeleri üzerinde etkili olduğu, matematiğe yönelik kaygılarını azalttığı ve kendilerine güvenlerinin artığı yönünde görüş bildirmişlerdir. Aşağıda sorulan her soru için bu bulguyu destekleyen bazı öğrencilerin ifadelerine yer verilmiştir:

“Etkinlikler akademik başarını artırdı mı?” sorusu ile ilgili öğrenciler;

"Etkinliklerimizi tamamlayarak yeni konuya geçmemiz yeni öğrenilen konuları daha iyi anlamamızı sağladı".

"Önceki bildiğimiz bilgilerin bazılarını unutmuşum. Siz tekrar edince hatırladım. Sonra yeni bilgileri ögrenmem konuları anlamam kolay oldu".

"Unuttuğum bazı konuları hatırlayarak yeni konu ögrenmem bilgimi artırdı... Karşılaştığım farklı soruları da çözebiliyorum" ifadelerini 
kullanmışlardır.

“Etkinlikler öğrenme üzerinde etkili miydi?” sorusu ile ilgili öğrenciler;

“... Sadece matematik dersi değil, burada yaptı̆̆ımı etkinlikler başka derslerimizi de olumlu yönde etkiledi".

"Önce, önceki konuları tekrarlamamı yavaş yavaş öğreneceğimiz konuya geçmemiz güzel oldu. Her çalı̧̧ma konusunda dört etkinlik olmast ögrenmemi güçlendirdi".

"Matematiğin bu kadar kolay olduğunun farkına vardım. Evde kendim artık çalışabiliyorum" ifadelerini kullanmışlardır.

"Etkinlikler matematiğe yönelik kaygı/korkunu azalttı mı?" sorusu ile ilgili öğrenciler;

"Matematik dersinin görüldüğ̈̈ gibi zor olmadığını gördüm. Benim de rahatllkla yaptı̆̆ım etkinlikler oldu".

“...Özellikle problem çözmenin zor olduğunu düşünüyordum. Şimdi bir problemi sayıların yanında şekillerle de çözebileceğimi düşünüyorum..."

“...Bir problemi çözerken farkl yolları deneyebiliyorum. Derse girerken herhangi bir kaygl hissetmiyorum. Fen dersinde de hissetmemeye başladım" ifadelerini kullanmışlardır.

“Etkinlikler sonucunda kendine güvenin arttı mı?” soru ile ilgili öğrenciler;

“... Öğrendiğim konular ile ilgili soruları çözebiliyorum. Çözemesem de şekil ile çözmeye çalışlyorum. Sonuca bir şekilde ulaşlyorum”.

"Öğrendiğim soruları çözdükçe kendime güvenim arttı ... Yani soru çözme isteğim doğuyor".

“...Sadece matematikte değil, başka derslerde de kendime güvenimin artığını gördüm" ifadelerini kullanmışlardır.

\section{Sınıf Ortamına Yönelik Öğrenci Görüşleri}

Öğrencilere "sınıf ortamına yönelik" ana temasına ait bir adet açık uçlu soru sorulmuştur. Öğrencilerin, "Çalışma yapraklarına dayalı olarak gerçekleştirilen ders hakkındaki görüşlerin nelerdir?" sorularına verdikleri yanıtlar Tablo 16'da gösterilmiştir.

Tablo 16. Sınıf Ortamına Yönelik Öğrenci Görüşlerine Ait Bulgular

\begin{tabular}{|l|c|}
\hline Öğrenci Görüşü & Öğrenci \\
\hline Etkinlikler öğrenmemi kolaylaştırdı. & 7 \\
\hline Etkinlikler bildiklerimizi kullanarak bilemediklerimizi yapmamızı sağladı. & 4 \\
\hline Etkinliklerle konuları yetiştirebilmek için zaman kısıtlıydı. & 10 \\
\hline Bazı etkinliklerde zevk alırken bazılarında sıkıldım. & 1 \\
\hline Değerlendirme sorularını yapabilmek bana güven sağladı. & 4 \\
\hline Her konuda dört etkinlik vardı. Bazılarını kolay yaparken, bazılarında zorlandım. & 6 \\
\hline Sınıf mevcudunun kalabalık olmasından dolayı bazen bana sıra gelmedi. & 3 \\
\hline Beraber çalışmalar sırasında sınıf kalabalık olduğu için gürültü oluyordu. & 3 \\
\hline Derse aktif olarak katılmamı sağladı. & 6 \\
\hline
\end{tabular}

Tablo 16 incelendiğinde öğrencilerin, sınıfta uygulanan etkinliklerle daha kolay öğrendikleri, 
derse aktif olarak katıldıkları, ön öğrenme eksikliklerinin giderilmesi sayesinde yeni konuyu kolayca anlayabildikleri ve soruları rahatlıkla çözebildikleri görülmektedir. Diğer taraftan öğrenciler, sınıf mevcudunun kalabalık olması nedeniyle az da olsa gürültülü bir ortam oluştuğunu ve ders süresinin kısıtlı olduğunu vurgulamışlardır. Aşağıda bu bulgurları destekleyen bazı öğrencilerin ifadelerine yer verilmiştir:

“...Sinıf sanki bir atölye gibiydi. Diğer işlediğimiz derslere hiç benzemiyordu".

"Derste bazen zaman yetmiyor. Ders çok çabuk bitiyor. Resim yaparak da matematik ögrendiğimi gördüm".

“...Aynı yaprakta birden fazla etkinlik var. Bu etkinliklerin bazıların yaparken zorlandım. Bazılarını kolaylıkla yaptım. Etkinlikleri yaptıkça kendime güvenim arttı".

“...Bu etkinlikleri severek yapıyorum. Zaman bazen yetiştiremiyorum”.

Dersin işlenişine yönelik öğrenci görüşlerine baktığımızda öğrencilerin, etkinliklerin dersi eğlenceli hale getirdiğini, derse aktif olarak katıldıklarını belirtmekle beraber, değiştiren öğrenme stiline sahip öğrencilerin; matematik dersi değil de sanki görsel sanatlar, beden eğitimi gibi bir derste olduklarını ifade etmişlerdir. Yerleştiren öğrenme stiline sahip öğrencilerin; kendilerinin etkinlik hazırlamalarından ve boyamalardan bazı ders araçlarını kendilerinin hazırlamalarından mutlu oldukları, özümseyen öğrenme stiline sahip öğrencilerin; geometrik çizimlerden, kesirler ve kesir çizimlerinden zevk aldıkları, ayrıştıran öğrenme stiline sahip öğrencilerin; oyun oynayarak öğrenmekten hoşlandıkları, görülmüştür.

Matematik öğretimine yönelik öğrenci görüsslerine bakıldığında, görüşme formu dolduran öğrencilerin tamamının etkinliklerin matematik başarısını artırdığı, öğrenme üzerinde etkili olduğu, matematiğe yönelik kayg1/korkunun azaldığı, kendine güveninin artı̆̆ görüşü oluşmuştur. Öğrenme stiline göre değiştiren öğrenme stiline sahip öğrencilerin, bir problem çözerken farkl yolları deneyebiliyorum, derse girerken herhangi bir kayg hissetmiyorum ayrıca Fen dersinde de hissetmemeye başladım. Her çalışma sonunda dört etkinlik olması ögrenmemi güçlendirdi şeklinde ifade etmişlerdir. Yerleştiren öğrenme stiline sahip öğrencilerin; sadece matematik dersinde değil başka derslerde de kendime güvenim artığın gördüm, bir konu üzerinde görüş bildirebiliyorum, özümseyen öğrenme stiline sahip öğrencilerin; şekillerle öğrenmem bir problemi alternatif yollarla çözebilmem bir sonraki konu için farklı düşünmemi sağladı. Konuları unutmadı̆̆ımı gördüm. Sadece matematik dersi değil, burada yaptığımı etkinlikler başka derslerimizi de olumlu yönde etkiledi gibi ifadeler yer almaktadır. Ayrıştıran öğrenme stiline sahip öğrenciler ise; Özellikle problem çözmenin zor olduğunu düşünüyordum. Şimdi bir problemi sayıların yanında şekillerle de çözebileceğimi düşünüyorum şeklinde görüş belirtmişlerdir.

Sınıf ortamına yönelik öğrenci görüşlerine baktığımızda genel olarak öğrencilerin; sınıf mevcudu kalabalık olduğu için bazen bana sıra gelmedi, etkinlikler genelde derse aktif olarak katılmamı sağladı, beraber çalışmalarımızda sınıf kalabalık olduğu için gürültü oluyordu gibi görüşler belirtmişlerdir. Öğrenme stiline göre değiştiren öğrenme stiline sahip öğrencilerin, Özellikle değerlendirmelerde farkl etkinliklerin olması öğrenmemizi kolaylaştırdı. Bir de bütün sinıf derse katıllyordu. gibi görüşlerin, Yerleştiren öğrenme stiline sahip öğrencilerin; Sinıf sanki bir atölye gibiydi. Diğer işlediğimiz derslere hiç benzemiyordu., grup çalışmalarında farkında olmadan öğrendiğimi gördüm. Zaman bazen yetmiyordu görüşünün, özümseyen öğrenme stiline sahip öğrencilerin; Yalnız yapabildiğimden yapamadığıma doğru çalışmamız 
öğrenmemizi kolaylaştırdı. ... Sadece arkadaşlarımla beraber çalışırken biraz gürültü oluyordu görüşü Ayrıştıran öğrenme stiline sahip öğrencilerin ise; Bir de oyun, grup çalışmalarında farkında olmadan ögrendiğimi gördüm. Zaman bazen yetmiyor görüşlerinde olduğu görülmüştür

\section{Sonuç ve Tartışma}

$\mathrm{Bu}$ araştırmada, bulgular doğrultusunda ulaşılan sonuçlar aşağıda özetlenmektedir.

1. Kolb'un öğrenme stillerine göre hazırlanan etkinliklerin uygulandı $\breve{g} l$ deney grubu ögrencilerinin kontrol grubuna göre tutum, öz-yeterlik ve kalıcllı düzeylerinin artığl, kaygl düzeylerinin ise azaldı ̆̆ tespit edilmiştir.

Öğrencilerin öğrenme stilleri eğitim gördükleri alana yönelik geliştirdikleri tutumlar1 etkilediği, tutumların da öz-yeterlikleri etkilediği düşünüldügünde, öğrencilerin öğrenme stilleri dolaylı olarak öz-yeterliklerini etkilemektedir (Kahyaoğlu 2011). Ayrıca eğitim-öğretimin temel amac1 bireylerin belirlenen davranışlar yönünde yetişmelerini sağlamak ise, öğrenme yaşantılarının öğrenme stillerine uygun olarak düzenlenmesi, amaçlara daha kolay ulaşılmasını sağlayabilir. $\mathrm{Bu}$ durum sağlanamadığı takdirde, sonuçta aynı zekâya sahip öğrencilerden biri başarılı olurken diğeri başarısız olabilir (Ekici 2002; Mutlu \& Aydoğdu 2003). Dwyer (1996) ise, hangi öğrenme ortamında olunursa olunsun, öğrencilerin öğrenme stillerinin dikkate alınarak sürecin tasarlanması gerektiğini vurgulamaktadır (Kılıç \& Karadeniz 2006).

Bireylerin kendi öğrenme stillerinin farkında olarak öğrenme-öğretme sürecinde bulunmalarının sağlanması ve akademik başarı, özgüven gibi özelliklerinin geliştirilebilmesi için, küçük yaşlardan başlayarak öğrenme stili özelliklerinin belirlenmesi gerekmektedir. Öğrencilerin bir dersten başarılı olmalarını etkileyen faktörlerden bir diğeri ise öğrencilerin iyi çalışma, tutum ve alışkanlıklarına sahip olmalarıdır (Küçükahmet 2000). Öğrenme stillerine yönelik yapılan öğretim uygulamalarının özellikle karmaşık üst düzey öğrenmelerde akademik başarıyı artırmakla kalmamakta; aynı zamanda öğrencilerin birbirlerine olan güvenlerini, konu alanına ilişkin tutum ve ilgilerini de geliştirdiği bilinmektedir (Doymuş et al. 2004).

Strateji kullanımının öğrenmeyi kolaylaştırdı̆̆ı, buna bağlı olarak da yeterlilik duygusunu geliştirdiği söylenebilir. Bunun yanı sıra kaygı düzeyinin yüksek olmaması yine öğrenmeyi kolaylaştıran faktörlerdendir. Buna bağlı olarak öz yeterlik inancının olumlu etkilenmesi beklenen bir durum olarak düşünülebilir (Köse 2010).

2. Öğrencilerin öğrenme stillerinin bilinmesi, öğretim stratejileri, öğretim yöntem ve teknikleri ve gerekli ögretim materyallerinin seçilmesinde kolaylık sağlamaktadır.

Sınıfta birden fazla öğrenme stiline sahip bireyler olması durumunda öğrenme stilleri envanteri kullanılarak, öğrencilerin öğrenme stilleri tespit edilebilir ve böylece uygun strateji, metot, teknik ve materyal kullanımı ve dolayısıyla da öğrenmede etkililik ve kalıcılık sağlanabilir. Bu yaklaşım aynı zamanda sınıftaki başarılı ve başarısız öğrenci grupları arasındaki uçurumu da azaltacak ve öğrenmeye daha uygun bir ortam hazırlayacağı düşünülmektedir (Güven 2007). Yapılan çalışmada; grupların son test ortalama puanları ve kalıcılık testi ortalama puanları ön test ortalama puanlarına göre daha yüksek olduğu tespit edilirken, son test ve kalıcılık testi puanları arasındaki fark anlamlı bulunmamıştır. Bu bulgu Kolb’un öğrenme stillerine göre düzenlenen matematik dersini alan öğrencilerin kalıcılık düzeylerinin uygulama sonrasında ve daha sonra yapılan ölçümlerde anlamlı ölçüde artığını, uygulama sonrasındaki kalıcılık düzeylerinin ise daha sonra yapılan izleme çalışmalarındaki ölçüm sonuçlarından farklılaşmadığını, yani uygulamanın etkisinin devam ettiğini göstermektedir. Bu bulgu Güven (2007) ve Azar'ın (2008) çalışma sonuçlarıyla paralellik göstermektedir. 
3. Ön ögrenme eksikliklerinin giderilmesi ve öğrenme stillerine dayalı hazırlanan etkinlik süreci ile ilgili deney grubu öğrencilerinin, "dersin işlenişine yönelik", "sinıf ortamına yönelik" ve "matematik ögrretimine yönelik" görüşlerinin genel olarak olumlu olduğu tespit edilmiştir.

Dersin işlenişine yönelik öğrenci görüşleri incelendiğinde; etkinliklerle matematik öğretiminin, tüm öğrenciler için dersi eğlenceli hale getirdiği ve derse katılımlarını artırdığı görülmüştür. Kolb'un öğrenme stillerine dayalı hazırlanan etkinliklerin öğrencilerin öğrenme özelliklerine hitap etmesi, etkinliklerin tartışma ve işbirliğiyle yapılması ve özellikle öğrenci görüşlerinin alınması, tüm öğrencilerin derse aktif katılımını sağladığı söylenebilir. Öğrencilerin görüşlerine göre, sınıfın kalabalık olması ve zamanın kısıtlı olması yapılan etkinlikleri aksatmamış, aksine ders içinde ilgi çekici materyallerle konuyu öğrenmeye çalışmaları dolayısı ile derse karşı ilgi ve motivasyonlarını artırdığı görülmüştür.

Matematik öğretimine yönelik öğrenci görüşleri incelendiğinde; ön öğrenme eksikliklerinin giderilerek, etkinliklerle matematik öğretiminin, tüm öğrencilerin hem matematik dersi hem de diğer derslerdeki başarılarını artırdığı tespit edilmiştir. Bunun yanında derse aktif olarak katılan öğrenciler, oyun, şekil, bulmaca gibi materyaller yardımıyla verilen öğretimin, öğrenmelerine olumlu yönde etki ettiğini ifade etmişlerdir. Matematik dersini önceden zor görüp, konuları rahatlıkla öğrendiklerini fark eden öğrenciler, derse karşı kaygılarının azaldığını ve kendilerine güvenlerinin artığını belirtmişlerdir.

Sınıf ortamına yönelik öğrenci görüşleri incelendiğinde ise; ön öğrenme eksikliklerinin giderilerek, etkinliklerle işlenen matematik dersinin genel olarak zevkli geçtiği ancak zamanın kısıtlı olması nedeniyle öğrencilerde, etkinlikleri ve konuları yetiştirememe kaygısı oluştuğu görülmektedir. Ayrıca sınıf mevcudunun kalabalık olması ortamın az da olsa gürültülü olmasına neden olmuş ve bazı öğrenciler söz alma konusunda sıkıntı yaşamışlardır. Bu olumsuzluklara rağmen öğrencilerin, etkinlikleri yaparken derse aktif olarak katılabildiği, eksik öğrenmelerinin giderilerek yeni bilgileri daha kolay öğrenmeleri sayesinde kendilerine güvenlerinin artığ ve derse karşı tutumlarının olumlu yönde değiştiği tespit edilmiştir.

Kolb, deneyimsel öğrenme kuramı ile belirttiği öğrenme stilleri sınıflamasında, bireylerin güçlü ve zayıf yönlerini belirterek, en uygun öğrenme şartları hakkında bilgiler vermektedir. Deneyimsel öğrenme kuramı ders etkinliklerinin sırasıyla; somut deneyim, yansitıcı gözlem, soyut kavramsallaştırma ve aktif deneyim öğrenme yollarına uygun olarak hazırlanmasını gerektirmektedir. Bu kuram, eğitimcilere her bir ders için çok çeşitli öğretim yöntem ve tekniklerinin uygulanma aşamalarını göstermekte, kalıcı ve bireysel öğretimin gerçekleşmesinde alternatif bir çözüm olarak göstermektedir (Bahar \& Bilgin 2003). Bu konuda Halaçoğlu (1999) çalışmasında üniversite öğrencilerinin öğrenme stilleri ile öğrenme stratejileri arasında anlamla bir iliş̧ki olmadığını belirtmiştir.

Öğrenme stillerine dayalı eğitimin öğrencilerin başarısını artırdığını ve bu artışın öğrenme stillerine göre farklılaşmadığını ortaya koyan birçok araştırma bulgusu mevcuttur. Williams (1990) İnsan İlişkileri, Colins (1999) Tarih, Coğrafya, Whicker (2001) Tip, Nichols (2003) Biyoloji derslerinde, deneyimsel öğrenme kuramına dayalı eğitimin öğrenci başarısını artırdığını ve bu artışın öğrencilerin öğrenme stillerine göre farklılaşmadığını ortaya koymuştur. Bu bilgiler dikkate alınarak hazırlanan etkinliklerin öğrencilerin dersin işlenişine, sınıf ortamına ve matematik öğretimine yönelik görüşlerini olumlu yönde etkilediği görülmektedir. Kolb’un deneyimsel öğrenme kuramına dayalı olarak düzenlenen eğitim etkinliklerinin öğrenci başarısı ve duyuşsal durumları üzerinde olumlu etkisi olduğunu ortaya koyan birçok araştırma sonucu bu bulgularla da örtüşmektedir 


\section{Öneriler}

Araştırma doğrultusunda getirilen öneriler uygulayıcılara yönelik ve araştırmacılara yönelik olmak üzere aşağıda verilmiştir.

1. Örneklemde yer alan öğrencilerin çoğunluğunun $(\% 35,14)$ değiştiren öğrenme stiline sahip olduğu belirlenmiştir. Ancak her bir stil grubundaki öğrenci sayısının azımsanamayacak düzeyde olduğu görülmüştür. (\%29,73 yerleştiren, \%24,32 ayrıştıran, \%10,81 özümseyen). Küçük bir öğrenci grubu üzerinde ulaşılan bu belirleme dikkate alınmalı ve öğretmenlerin öğrenme sürecinde önemli bir etkisi olan öğrenme stilleri konusunda bilgilendirilmeleri için hizmet içi eğitim programları geliştirilmeli ve uygulanmalıdır.

2. Ön öğrenme eksikliklerinin giderilerek Kolb'un öğrenme stillerine dayalı etkinliklerle öğretim yapılması öğrencilerin Matematik dersi kalıcılık düzeylerini artırdığı belirlenmiştir. Matematik dersinin, aynı zamanda diğer derslerin etkili ve bireysel özelliklere uygun biçimde gerçekleştirilmesinde, deneyimsel öğrenme kuramından yararlanılmalidır.

3. Her eğitim kurumunun kendi bünyesinde öğrencilere yönelik öğrenme stili konulu seminerler vermesi yararlı olacaktır.

4. Sınıf içerisinde derslerde kullanılan yöntem, teknikler, araç-gereçler öğrencinin öğrenme stiline uygun olmalıdır.

5. Bu araştırmada İlköğretim 5. Sınıf matematik dersi bağımlı değişken olarak kullanılmıştır. Yapılması planlanan diğer çalışmalarda bu değişkenler; Fen ve Teknoloji, Türkçe, Sosyal vb. alanlarda da değerlendirilebilir.

6. Yapılacak olan araştırmalarda, öğrencilerin öğrenme stillerinin eğitim hayatlarının belirli dönemlerinde değişip değişmediği incelenebilir.

7. Kolb'un öğrenme stili ve ön koşul öğrenmelere dayalı hazırlanan etkinlikleri farklı öğretim kademelerinde de uygulanarak, hangi sınıfta daha etkili olduğu araştırılabilir.

8. İlköğretim Matematik dersinde öğrencilerin duyuşsal ve bilişsel kazanımlarını artırmada ve dersin daha eğlenceli bir hale getirilmesinde, öğrenme stillerine uygun sanal öğrenme çevreleri üzerinde araştırmalar yapılabilir.

\section{KAYNAKÇA}

Aksu M. (1985). Ortaöğretim Kurumlarında Matematik Öğretimi ve Sorunları. Ankara 1985.

Altun S. (2005). Öğrencilerin Öz Düzenlemeye Dayalı Öğrenme Stratejilerinin ve Öz Yeterlik Algılarının Öğrenme Stilleri ve Cinsiyete Göre Matematik Başarısını Yordama Gücü. Yayımlanmamış Doktora Tezi. Yıldız Teknik Üniversitesi, Sosyal Bilimler Enstitüsü, İstanbul 2005.

Arslan B. \& Babadoğan C. (2005). "İlköğretim 7. ve 8. Sinıf Öğrencilerinin Öğrenme Stillerinin Akademik Başarı Düzeyi, Cinsiyet ve Yaş İle İlişkisi”. Eurasian Journal of Educational Research 21 (2005) 35-48.

Aşkar P. \& Erdem M. (1986). Öğretmen Adaylarının Öğretmenlik Mesleğine Yönelik Tutumları. İstanbul 1986.

Aydın B. (2003). "Bilgi Toplumu Oluşumunda Bireylerin Yetiştirilmesi ve Matematik Öğretimi". Pamukkale Üniversitesi Ĕ̈itim Fakültesi Dergisi 2/14 (2003) 35-48.

Azar N. (2008). Fen ve Teknoloji Dersinde Öğrenme Stillerinin İşbirlikçi Grup Atamalarında Kullanılmasının Öğrencilerin Akademik Başarı, Tutum, Bilimsel Süreç Becerileri ve Öğrenmenin Kalıcılık Düzeylerine Etkisi. Yayımlanmamış Yüksek Lisans Tezi. Zonguldak Karaelmas, Üniversitesi Sosyal Bilimler Enstitüsü, Zonguldak 2008. 
Bahar M. \& Bilgin İ. (2003). "Öğrenme Stillerini İrdeleyen Bir Literatür Çalışması". Abant İzzet Baysal Üniversitesi Sosyal Bilimler Enstitüsü Dergisi 1 (2003) 14.

Baykul Y. (2003). Illköğretimde Matematik Öğretimi 1-5 Sinıflar İçin. Ankara 2003.

Bıkmaz F. (2006). "Science Teaching Self-Efficacy Beliefs And Views About Effective Science Courses". Eurasian Journal of Educational Research 25 (2006) 34-44.

Biçer M. (2010). İlköğretim 6. 7. 8. Sinıf Öğrencilerinin Sinıf Düzeyleri. Cinsiyetleri. Akademik Başarıları ve Ders Grupları İle Öğrenme Stilleri Arasındaki İlişki. Yüksek Lisans Tezi. Yıldız Teknik Üniversitesi, Sosyal Bilimler Enstitüsü, İstanbul 2010.

Bindak R. \& Özgen K. (2008). "Matematik Okuryazarlığı Öz-Yeterlik Ölçeğinin Geliştirilmesi”. Kastamonu Ĕ̈itim Dergisi 16/2 (2008).

Bindak R. (2005). "İlköğretim Öğrencileri İçin Matematik Kaygı Ölçeği”. F.Ü. Fen ve Mühendislik Bilimleri Dergisi 17/2 (2005) 517-528.

Büyüköztürk Ş., Bökeoğlu Ö. Ç. V. \& Köklü N. (2009). Sosyal Bilimler İçin Istatistik. Ankara 2009.

Büyüköztürk Ş. $\left(2010^{11}\right)$. Sosyal Bilimler İçin Veri Analiz El Kitabı. Ankara 2010.

Büyüköztürk Ş. $\left(2012^{11}\right)$. Bilimsel Araşttrma Yöntemleri. Ankara 2012.

Colins M. (1999). Kolb's Experiential Learning Theory and History Achievement. Source: http://wwwweb1.epnet.com/citaton.asprds.

Coşkun N. (2011). Öğrenme Biçemlerine Göre İlköğretim Öğrencilerinin Matematik Dersi Başarı ve Kaygı Düzeyleri. Yayımlanmış Yüksek Lisans Tezi. Dokuz Eylül Üniversitesi, Eğitim Bilimleri Enstitüsü, İzmir 2011.

Deniz K. Z. \& Kelecioğlu H. (2005). İlköğretim Başarı Ölçüleri İle Ortaöğretim Kurumları Öğrenci Seçme ve Yerleştirme Sınavı Arasındaki İlişkiler. Ankara Üniversitesi, Eğitim Bilimleri Fakültesi Dergisi 38/2 (2005) 127-143.

Doğan N. \& Sevindik H. (2011). “İlköğretim 6. Sınıflar İçin Uygulanan Seviye Belirleme Sınavı'nın Uygunluk Geçerliği”. Eğitim ve Bilim 36/160 (2011) 309-319.

Doymuş K, Şimşek Ü. \& Bayrakçeken S. (2004). “İşbirlikçi Öğrenme Yönteminin Fen Bilgisi Dersinde Akademik Başarı ve Tutuma Etkisi”. Türk Fen Eğitimi Dergisi 1/2 (2004) 103-115.

Dursun Ş. \& Dede Y. (2004). "Öğrencilerin Matematikte Başarısını Etkileyen Faktörler: Matematik Öğretmenlerinin Görüşleri Bakımından”. Gazi Eğitim Fakültesi Dergisi 24/2 (2004) 217-230.

Dursun Ş. \& Bindak R. (2011). "İlköğretim II. Kademe Öğrencilerinin Matematik Kaygılarının İncelenmesi”. CÜ Sosyal Bilimler Dergisi 35/1 (2011) 18-21.

Ekici G. (2002). "Gregorc Öğrenme Stili Ölçeği”. Eğitim ve Bilim Dergisi 123 (2002) 42-47.

Elçi A. N. (2008). Öğrenme Stillerine Uygun Olarak Seçilen Öğrenme Yöntemlerinin Öğrencinin Başartsina, Matematiğe Yönelik Tutumuna ve Kaygısına Etkileri. Yayımlanmamış Doktora Tezi. Dokuz Eylül Üniversitesi Eğitim Bilimleri Enstitüsü, İzmir 2008.

Forney D. S. (1994). "A Profile Of Student Affairs Master's Students: Characteristics, Attitudes, and Learning Styles". Journal of College Student Development 35 (1994) 337-345.

Gencel İ. E. (2006). Öğrenme Stilleri, Deneyimsel Öğrenme Kuramına Dayalı Eğitim, Tutum ve Sosyal Bilgiler Program Hedeflerine Erişi Düzeyi. Yayımlanmış Doktora Tezi. Dokuz Eylül Üniversitesi Eğitim Bilimleri Enstitüsü, İzmir 2006.

Gray E. \& Tall D. (1993). "Success And Failure in Mathematics: The Flexible Meaning of Symbols As Process And Concept". Mathematics Teaching 142 (1993) 6-10.

Gren S. B. Salkind, N. J. \& Akey T. M. (2000). Using SPSS for Windows Analyzing and Understanding Data. New Jersey 2000.

Güven Z. (2007). Öğrenme Stillerine Dayalı Etkinliklerin Öğrencilerin Dinleme Becerisi Erişileri, Ingilizce Dersine Yönelik Tutumları ve Öğrenilenlerin Kalıcılığına Etkisi. Yayımlanmamış Doktora Tezi. Selçuk Üniversitesi, Sosyal Bilimler Enstitüsü, Isparta 2007.

Güzeller C. (2005). "İlköğretim Akademik Başarı Not Ortalamaları İle OKÖSYS Alt Test Puanları Arasındaki Uygunluk Geçerliği Çalı̧̧ması”. Gazi Üniversitesi Kırşehir Eğitim Fakültesi 6/2 (2005) 133-143.

Hallaçoğlu M. (1999) The Effect of Cognitive Styles on Learner Prefences. Yayımlanmamış Yüksek 
Lisans Tezi. Çukurova Üniversitesi, Sosyal Bilimler Enstitüsü, Adana 1999.

Haynes A. F., Mullins A. G. \& Stein B. S. (2004). "Differential Models for Math Anxiety in Male and Female College Students". Social Spectrum 24/3 (2004) 295-318.

Hein T. L. \& Budny D. D. (1999). "Teaching to Students' Learning Styles: Approaches That Work". Paper Presented $29^{\text {th }}$ ASEE/IEEE Frontiers in Education Conference, San Juan, Puerto Rico, November.

Kahyaoğlu M. (2011). “Öğretmen Adaylarının Öğrenme Stilleri ile Çevre Eğitimi Öz-Yeterlikleri Arasındaki İlişki”". Eğitim Bilimleri Araştırmaları Dergisi 1/2 (2011) 67-82.

Kılıç E. \& Karadeniz Ş. (2006). "Cinsiyet Ve Öğrenme Stilinin Gezinme Stratejisi Ve Başarıya Etkisi". GÜ. Gazi Ĕ̈itim Fakültesi Dergisi 24/3 (2006) 129-146.

Koç S. (2009). İlköğretim 5. Ve 6. Sinıf Öğrencilerinin Öğrenme Stillerinin Belirlenmesi ve Akademik Başarı ile İliş̧kisi. Yayımlanmış Yüksek Lisans Tezi. Fırat Üniversitesi, Sosyal Bilimler Enstitüsü, Elazı̆̆ 2009.

Kolb D. A. (1984). Experiential Learning Experience as the Source of Learning and Development. New Jersey 1984

Köse A. (2010). Fen Bilgisi Öğretmen Adaylarının Öğrenme Stilleri, Ders Çalışma Stratejileri İle Fen Bilgisi Öğretimi Öz Yeterlik İnançları Arasındaki İlişki (Çomü Örneği). Yayımlanmış Yüksek Lisans Tezi. Çanakkale Onsekiz Mart Üniversitesi, Sosyal Bilimler Enstitüsü, Çanakkale 2010.

Küçükahmet L. (2000). Öğretimde Planlama ve Değerlendirme. Ankara 2000.

Mutlu M. \& Aydoğdu M. (2003). "Fen Bilgisi Eğitiminde Kolb’un Yaşantısal Öğrenme Yaklaşımı". Pamukkale Üniversitesi Eğitim Fakültesi Dergisi 1/13 (2003) 15-29.

Nichols J. (2003). "The Effects of Kolb's Experiential Learning Theory on Achievement and Attitude". Source: http://wwwweb1.epnet.com/citation.asprds.

Özer D. (2010). İlköğretim 7. Sinı Öğrencilerinin Öğrenme Stilleri ile Problem Çözme Becerileri Arasındaki İlişkinin Incelenmesi. Yayımlanmamış Yüksek Lisans Tezi. Mehmet Akif Ersoy Üniversitesi, Sosyal Bilimler Enstitüsü, Burdur 2010.

Pajares F. (2003). "Self-Efficacy Beliefs, Motivation, and Achievement in Writing: A Review of the Literature". Reading \& Writing Quarterly 9 (2003) 139-158.

Renzulli J. S. (1996). "Schools for Talent Development. A Practical Plan for Total School Improvement". School Administrator 33 (1996) 20-22.

Saka A. Z. \& Kıyıcı F. B. (2004). "Öğrencilerin Fen Bilgisi Dersine Karşı Tutumlarını Etkileyen Faktörlerin Belirlenmesi”. Sakarya Üniversitesi Ĕgitim Fakültesi Dergisi 8 (2004) 376397.

Tekin H. (1993). Eğitimde Ölçme ve Değerlendirme. Ankara 1993.

Turgut F. (1984). Eğitimde Ölçme ve Değerlendirme Metotları. Ankara 1984.

Umay A. (1997). Illkokulun İlk Sinıflarında Ölçme, Değerlendirme ve Not Verme. Nasıl Eğitim Sistemi: Güncel Uygulamalar Ve Geleceğe İlişkin Öneriler Eğitim Sempozyumu, İzmir. (1997) 477-484.

Whicker B. (2001). Effects of Experiential Learning Theory. Source: http://wwww.epnet.com/citation.asprds

Williams A. M. (1990) Effects of Experiential Learning on Knowledge Acquisition, Skill Mastery and Student Attitudes. Source: http//www.lib.umi.com/dissertations/fullcilt/9104729

Yenilmez K. (2010). "Ortaöğretim Öğrencilerinin Matematik Dersine Yönelik Umutsuzluk Düzeyleri”. Hacettepe Üniversitesi Ĕ̈itim Fakültesi Dergisi 38 (2010) 307-317.

Yurtseven R. (2010). İlköğretim Beşinci Sinıf Öğrencilerinin Sosyal Bilgiler Dersindeki Akademik Başarıları İle Öğrenme Stilleri Arasındaki İlişki. Yayımlanmış Yüksek Lisans Tezi. Afyon Kocatepe Üniversitesi, Sosyal Bilimler Enstitüsü, Afyonkarahisar 2010. 